\title{
CHEMICAL, SENSORY, PHYSICAL AND MICROBIOLOGICAL EVALUATION OF THREE NOVEL MILK BEVERAGES FOR CHILDREN
}

\author{
By \\ El-Zainy, A.R.M. \\ Home Economics Dept., \\ Faculty of Specific Education, \\ Mansoura University, Egypt. \\ El-Zamzamy, F.M. \\ Home Economics Dept., \\ Faculty of Specific Education, \\ Mansoura University, Egypt.

$$
\text { Mostafa, M.Y.A. }
$$ \\ Home Economics Dept., Faculty of Specific Education, \\ Mansoura University, Egypt.
}

Research Gournal Specific Education

Faculty of Specific Fducation

Mansoura University

ISSUE NO. 31, JULY. 2013

مجلة بحوث التربية النوعية ـ جامعة المنصورة

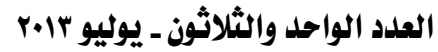




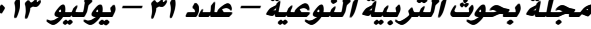 \\ CHEMICAL, SENSORY, PHYSICAL AND MICROBIOLOGICAL EVALUATION OF THREE NOVEL MILK BEVERAGES FOR CHILDREN
}

\author{
El-Zainy, A.R.M. ${ }^{*} \quad$ El-Zamzamy, F.M.* Mostafa, M.Y.A. \\ Abstract
}

This work was carried out to study effect substitution of corn grits with $5 \%$ sweet potato or pumpkin grits for processing corn snacks using extrusion cooking techniques . The most favorable conditions for operator device were determined namely: feed moisture content, speed screw and extruder barrel temperature .Sensory evaluation such as color, taste, appearance, crispness and over all acceptability on the final product characteristics were studied. Three factors were identified for the operation as follows :feed moisture contents(16, 18 and 20\%), screw speed(120, 140, $160 \mathrm{rpm})$ and barrel temperature $\left(130,150\right.$ and $\left.170{ }^{\circ} \mathrm{C}\right)$ and the impact on the physicochemical properties such as bulk density (BD), expansion rate(ER) and water solubility index \%( WSI \%). The results indicated that the suitable expansion ratio were 2.01 and $2.62 \mathrm{gm} / \mathrm{cm} 3$ and the swelling percentage were 3.5 to $3.4 \%$, respectively checks at $16 \%$ and $18 \%$ moisture for blend snacks1 ( $95 \%$ corn grits $+5 \%$ sweet potato grits )and blend snacks 2 ( $95 \%$ corn grits $+5 \%$ pumpkin grits), while the proper screw speed ( 120 and $140 \mathrm{rpm}$ ) by high barrel temperature ( 130 and $150 \mathrm{oc}$ ). The results showed significant differences in the color, taste, appearance, crispness and over all acceptability in each of the blend 1 and 2 as compared to the control (100\% corn grits snacks) and had a best appearance of the blend 1 and the highest values for color, taste and over all acceptability for the blend 2. So, it can be concluded that the process of extrusion device cooking heat the most suitable for operation is content feed humidity $16 \%$ ,temperature $130{ }^{\circ} \mathrm{c}$ and the speed screw120rpm for a blend 1 and $18 \%$

\footnotetext{
* Home Economics Dept., Faculty of Specific Education, Mansoura University, Egypt
} 
moisture, $150^{\circ} \mathrm{c}$ and $140 \mathrm{rpm}$ for the blend 2 to produce a product acceptable corn Snacks, and on the other the use of $5 \%$ of the sweet potatoes grits or pumpkin grits for the production of corn snacks contributed positively to show the desired qualities of a product such as increasing the expansion rate , improved crispness, taste and overall acceptability. This study highlights the importance of the selection experimentally the impact of new ingredients on different variables when manufacturing snacks from corn snacks.

Keywords: Extrusion, Snacks, Screw Speed, Sweet Potato, Pumpkin, Corn grits and sensory. 
مجلة بحوث التربية النوعية - علد الr - يوليو rا.r

\title{
CHEMICAL, SENSORY, PHYSICAL AND MICROBIOLOGICAL EVALUATION OF THREE NOVEL MILK BEVERAGES FOR CHILDREN
}

\author{
El-Zainy, A.R.M. ${ }^{*} \quad$ El-Zamzamy, F.M. ${ }^{*}$ Mostafa, M.Y.A.
}

\section{Introduction:-}

In the early years milk fruit juice mixes were known. They have always been appreciated and gained wide popularity and acceptance. These mixes continued to be in production in many countries as they offer a variety of cocktails mixed with milk are processed and gained great acceptance. Nicklas (2003) said that milk consumption -by increasing calcium intake-protects people from a variety of dangerous medical conditions. These include hypertension, colon cancer, breast cancer, ovarian cancer, kidney stones, insulin resistance syndrome, obesity, and lead poisoning. cow's milk consumption has several benefits. Studies show that children who consume milk products have reduced risk of protein malnutrition, fewer dental cavities, increased mineral content in their bones and fewer bone fractures and reduce risk of developing rickets (Edwards et al., 2007). On the other hand Wiley (2005) reported that U.S. study found that milk consumption was linked with taller teenagers, even after controlling for age, sex, household income, and ethnicity, while consumption of milk is effective at promoting muscle growth and improving post exercise muscle recovery by Chavarro et al. (2007). In addition, Wiley (2009) reported that a U.S. study found that preschool children who were in the top $25 \%$ for milk consumption were about a centimeter taller than their peers. Liu (2007) mentioned that phytochemicals and antioxidants in whole grains such as wheat have not received as much attention as the phytochemicals in fruits and vegetables although the increased consumption of whole grains and whole grain products has been associated with reduced risk of developing chronic diseases such as cardiovascular disease, type 2

* Home Economics Dept., Faculty of Specific Education, Mansoura University, Egypt 
diabetes, some cancers and all-cause mortality. Bisig (2011) Stated that flavored milks are unfermented milks mixed with sugar, a flavor/aromagiving ingredient, and stabilizers. They cater to the desire of the consumers, especially children, for variety and a different experience in flavor. Important flavors are chocolate, coffee, vanilla, strawberry, malt extract and chocolate, and banana. Chocolate milk is the most popular flavored milk, especially with children (90\% like its taste) (Miller et al., 2007). Mango is a source of bioactive compounds with potential health-promoting activity: ascorbic and dehydroascorbic acids, carotenoids, phenolics compounds, fiber, terpenoids and others. Several studies have demonstrated the biological properties of compounds found in all parts of the mango plant, suggesting their beneficial effects on human health, particularly as antioxidant (Ribeiro and Schieber, 2010). Therefore the aim of this work was studying the effect of adding wheat to cow milk on chemical composition, sensory, physical and microbiological properties of the final product, then manufacturing three wheat milk beverages (WMB): Strawberry wheat milk beverage (SWMB), Mango wheat milk beverage and Chocolate wheat milk beverage (CWMB) and studying the effect of adding chocolate and fruit on their chemical, physical, sensory and microbiology properties.

Key words: Cow's milk, Wheat, Strawberry, Mango, Chocolate, Flavored milk beverages.

\section{MATERIALS AND METHODS}

\section{Materials:}

cow's milk, wheat (Triticum aeritinum), sugar, selected fresh mango fruits, selected fresh strawberry fruits and fine powdered chocolate "Nesquick" with ingredients (sugar, cocoa, soya lecithin, salt, vanillin and cinnamon) and manufactured in Egypt by Nestle Egypt S.A.E. were obtained from the local market. 


\section{Methods:}

\subsection{Preparation of raw materials:}

2.1.1. Preparation of wheat: The wheat grains were washed with tape water and soaked for 6 hours then, it was cooked in boiling water for half an hour even absorb water and were put on the quiet heat until full cooked, then it was minced well and pressed on filter to separate fibers. The produced extract without fiber was used as the wheat additive form to the beverages.

2.1.2. Preparation of milk and fruits: Cow's milk was mixed, filtered and boiled in water bath for $30 \mathrm{~min}$. Mango was washed with water, peeled off and destined. The flesh was packed in poly ethylene bags and stored in a deep freezer $\left(-18^{\circ} \mathrm{C}\right)$ until required. Strawberry was washed with water then, mixed in the blender without water until it becomes homogeneous juice. The flesh was packed in poly ethylene bags and stored in a deep freezer $\left(-18^{\circ} \mathrm{C}\right)$ until required.

\subsection{Preparation of beverages:}

2.2.1. Preparation of wheat- milk beverages: Different level of prepared wheat $(5 \%, 10 \%$ and $15 \%)$ were added with $2 \%$ sugar to cow's milk and mixed well, then this mixtures were pasteurized at $75^{\circ} \mathrm{C}$ for five minutes (Jaan, 2001), filled in glass bottles, covered, cooled and stored in the refrigerator at $(5 \pm 1)^{\circ} \mathrm{C}$. Beverage with $15 \%$ prepared wheat was chosen to be the best one according to the sensory evaluation and protein quality as shown in Table (1).

Table (1): Recipe of wheat milk beverages.

\begin{tabular}{|c|c|c|c|c|c|c|}
\hline \multirow{2}{*}{ Samples } & \multicolumn{2}{|c|}{ Milk } & \multicolumn{2}{c|}{ Wheat } & \multicolumn{2}{c|}{ Sugar } \\
\cline { 2 - 8 } & $\%$ & $\mathrm{Gm}$ & $\%$ & $\mathrm{Gm}$ & $\%$ & $\mathrm{Gm}$ \\
\hline "Control" Cow milk & 100 & 250 & 0 & 0 & 0 & 0 \\
\hline 5\% wheat milk beverage & 93 & 232.5 & 5 & 12.5 & 2 & 5 \\
\hline $10 \%$ wheat milk beverage & 88 & 220 & 10 & 25 & 2 & 5 \\
\hline 15\% wheat milk beverage & 83 & 207.5 & 15 & 37.5 & 2 & 5 \\
\hline
\end{tabular}


2.2.2. Preparation of fruit and chocolate beverages: Wheat-milk beverage with $15 \%$ wheat was produced as a control mix. Other three flavored beverages were prepared: 1) Strawberry wheat milk beverage was prepared by adding 5\% strawberry to the control. 2) Mango wheat milk beverage was prepared by adding 5\% mango to the control. 3) Chocolate wheat milk beverage was prepared by adding $10 \%$ chocolate powder to the control, then this mixtures were pasteurized at $75^{\circ} \mathrm{C}$ for five minutes (Jaan, 2001), filled in glass bottles, covered, cooled and stored in the refrigerator at $(5 \pm 1)^{\circ} \mathrm{C}$. The beverages were stored for 21 days and obtained beverages were taken at initial and after 3, 7, 14, 21 days during the storage period and assessed microbiologically, sensory, physically and chemically. The beverages with 5\% strawberry, 5\% mango and 10\% Chocolate were chosen to be the best one according to the sensory evaluation.

\subsection{Products analytical methods:}

\subsubsection{Chemical analysis:}

Determination of moisture, crude protein, crude fat, ash, carbohydrate content, energy and $\mathrm{pH}$ value were carried out in all samples as follows:

2.3.1.1. Determination of moisture, crude protein, and crude fat: Moisture, crude protein and crude fat were carried out according to the methods of A.O.A.C. (1995).

2.3.1.2. Ash contents: Ash contents were carried out according to the methods of A.O.A.C. (2000).

2.3.1.3. Carbohydrate content: Carbohydrate was calculated by the following equation: Carbohydrate $=100-(\%$ moisture $+\%$ protein $+\%$ fat $+\%$ ash)

2.3.1.4. Energy value: Energy value was calculated as described by Hawk et al., (1949) who

estimated by the following equation: Energy value $=(\%$ carbohydrate $* 4)+(\%$ protein $* 4)+(\%$ fat $* 9)$.

2.3.1.5. $\mathrm{pH}$ value: $\mathrm{pH}$ value was measured according to the method as described by Ling, (1963) using digital Orion pH meter, Model 
SA720 (Orion, USA) equipped with a souder (combined glass electrode).

2.3.1.6. Determination of Amino Acids: Amino acids content of beverages was determined according to Millipore co-operative (1987) using HPLC at National Research Center, Giza, Egypt. The apparatus used is Spectra-physics Analytical, Inc. Aoogg 600 with spectra focus optical scanning detector and spectra system UV 2000 detector and ultrasphere C18 Beckman column. The analysis was carried out using a gradient of Pico Tag solvent $\mathrm{A} \& \mathrm{~B}$ at $40^{\circ} \mathrm{C}$ and flow rate $1 \mathrm{ml} / \mathrm{min}$. Detection of the separated Pico - Tag amino acids at $254 \mathrm{~nm}$ wave length.

2.3.1.7. Protein quality: Essential amino acids index (EAAI) and biological value (BV) was calculated as described by Dessouki and Hassanin (1995). Amino acid score (AAS) was calculated for essential amino acid by using (Anon, 1985). AAS = AA/16 $\mathrm{gN} \div \mathrm{AA}$ of $(\mathrm{FAO} / \mathrm{WHO})\}$

Protein efficiency ratio (PER): The protein efficiency ratio of the test was based on their amino acid content according to Alsmeyer, et al. (1974). However the following equation was used:

$$
\begin{aligned}
& \text { PER1 }=0.684+0.456 \text { leucien }-0.047 \text { proline } \\
& \text { PER2 }=0.468+0.454 \text { leucien }-0.105 \text { tyrosine } \\
& B V=49.09+(10.53 \text { PER } 2)
\end{aligned}
$$

Grams consumed to cover the daily requirements of protein and essential amino acid for children (6 - 10 years) was calculated by using RDA (Anon, 1989).

$$
\text { GDR of protein }=63 * 100 /(\text { protein } \%) \text {. }
$$

Percent of satisfaction of protein and essential amino acids, when consumed $250 \mathrm{~g}$ from given beverage (PS / 250) were calculated by using RDA (Anon, 1989).

Essential amino acid, which showed the highest GDR value, is called restricting Amino Acid (RAA). 
2.3.2. Sensory evaluation of beverages: Sensory evaluation of beverages were carried out to determine their sensory characteristics according to Moor (1970) who recommended the following score (10) excellent, (9) very good, (8) good, (7) medium, (6) fair, (5) poor, (4) very poor, (3) extremely poor.

2.3.3. Physical analysis: Physical analysis of beverages was carried out in the Agricultural Research Center, Giza, Egypt as following:

2.3.3.1. Determination of total pectin content: Levels of pectin substances in beverage were determined colorimetrically by carbazole sulfuric acid method according to the method of Reitmier and Love (1996). Results were expressed as gm Anhydro Galacturonic Acid (A.G.A.) per $100 \mathrm{gm}$ on dry weight basis.

2.3.3.2. Determination of color index (O.D): Color index of fresh samples was determined according to the method of Hendel et al., (1950). Thus E 5\% $1 \mathrm{~cm} \mathrm{390nm,} \mathrm{refers}$ to the optical density of an extract prepared with 596 nes of material per $100 \mathrm{ml}$ of solvent, with transmittancy measured in a $1-\mathrm{cm}$ cell at $390 \mathrm{~nm}$.

2.3.3.3. Determination of total soluble solids (T.S.S): Total soluble solids were determined in beverages according to the method as described in A.O.A.C. (2000).

2.3.4. Microbiological analysis: Microbiological count data are expressed as colony forming units (CFU) per gram. Eight dilutions were carried out to determine the number of bacteria during storage. One $\mathrm{ml}$ of each dilution was aseptically plated in the media plate.

2.3.4.1. Enumeration of total bacterial count (TBC): Plat count agar medium (A.P.H.A., 1971) was used for detecting the total microbiological count. A known volume of sterile sample $0.1 \mathrm{ml}$ was added to Petri-plates containing agar medium, then the Petri-plates were incubated at $37^{\circ} \mathrm{C}$ for 48 hours. The total bacterial 


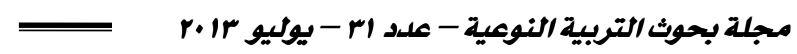

count was recorded as colony numbers per grams of samples.

2.3.4.2. Enumeration of spore formers bacterial count: Sporformars bacterial counts were determined according to Chalmer (1962) using nutrient agar medium.

2.3.4.3. Enumeration of yeast and moulds counts: Potato dextrose agar medium (Difico) used for moulds and yeasts count according to A.P.H.A. (1992). The plates were incubated at $30^{\circ} \mathrm{C}$ for 3.5 days.

2.3.5. Statistical analysis: All data were subjected to statistical analysis of variance (F-test) "one way ANOV". It is a procedure used for testing the differences among the means of two treatments. The significance of the measured data were considered as follows: not significant: (N.S) when P > 0.05; significant: $(\mathrm{S})$ when P < 0.05; high significant: (H.S) when $\mathrm{P}<0.01$. Where $\mathrm{P}$ is the probability (reflect of null hypothesis) Details of formulae used are given by Armitage (1971).

\section{RESULT AND DISCUSSION}

1. Wheat milk beverages:

\subsection{Chemical composition:}

1.1.1. Gross chemical composition $(\mathrm{g} / 100 \mathrm{~g} / \mathrm{ww})$ of raw materials:

Moisture, total protein, ash, fat, carbohydrates and energy of cow's milk and prepared wheat as raw materials were recorded in Table (2).

It can be observed that the prepared wheat recorded $(80.247 \pm 0.071$, $3.81 \pm 0.938, \quad 0.201 \pm 0.1, \quad 0.547 \pm 0.029, \quad 15.195 \pm 0.909$ and $80.943 \pm 0.466$ $\mathrm{g} / 100 \mathrm{~g}$ wet weight) for moisture, total protein, ash, fat, carbohydrate and energy, respectively. On the other hand the cow's milk recorded $(86.864 \pm 0.224,3.005 \pm 0.672,0.770 \pm 0.002,4.159 \pm 0.431,5.202 \pm 0.533$ and $70.259 \pm 2.979 \mathrm{~g} / 100 \mathrm{~g} \mathrm{ww}$ ) for moisture, total protein, ash, fat, carbohydrates and energy, respectively. 
It could be stated that prepared wheat has the highest protein, carbohydrates and energy contents, where as it has the lowest moisture, ash and fat contents when compared with the cow milk.

These results are in accordance with the data found by McCane et al. (2007) who found that milk composition analysis, per 100 grams wet weight was (water $87.8 \mathrm{~g}$ - fat $3.9 \mathrm{~g}$ - protein $3.2 \mathrm{~g}$ - carbohydrate $4.8 \mathrm{~g}$ energy $66 \mathrm{kcal}$ - sugars (lactose) 4.8g. Also Harold (1984) reported that in unhomogenized cow's milk, the fat globules average about four micrometers across. The fat-soluble

Table (2): Gross chemical composition of raw materials.

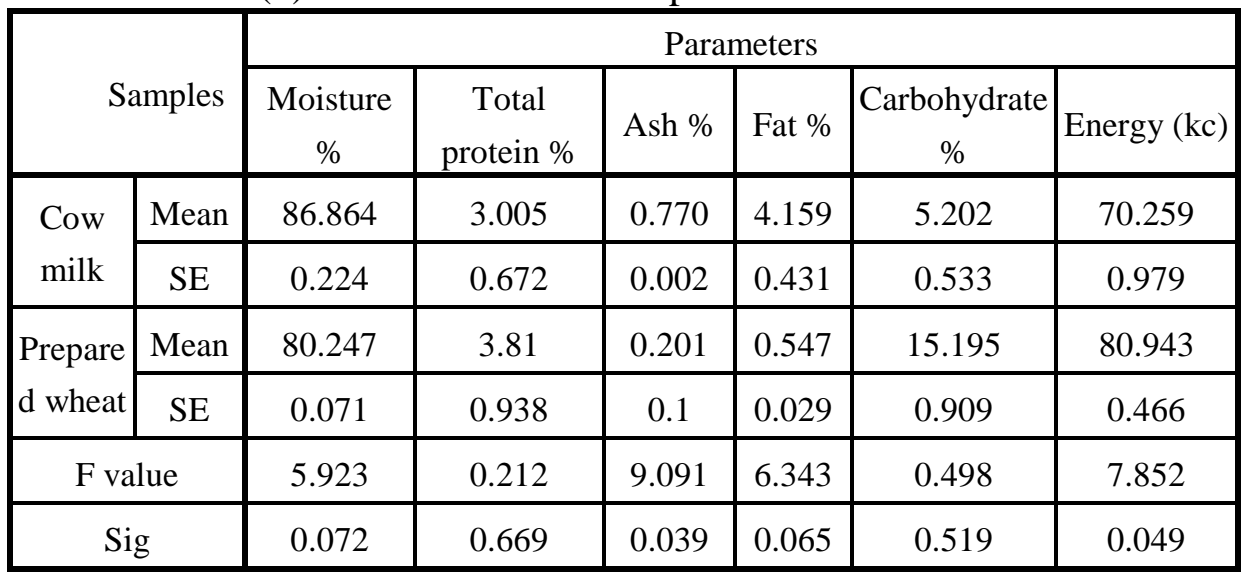

SE: Standard Error

vitamins $\mathrm{A}, \mathrm{D}, \mathrm{E}$, and $\mathrm{K}$ are found within the milk fat portion of the milk. The carbohydrates and lactose give milk its sweet taste and contributes approximately $40 \%$ of whole cow's milk's calories. Similar observations were reported by Guo (2011). Milk provides over $10 \%$ of the requirement of calcium, vitamin $\mathrm{D}$, magnesium, phosphorus, potassium, riboflavin, protein, and carbohydrates for most people (Moore et al., 2006). The levels of protein found in commercial UK winter wheat varieties vary between 10 and 14\% (Blanco et al., 1996). 


\subsubsection{Gross chemical composition ( $\mathrm{g} / 100 \mathrm{~g} / \mathrm{ww})$ of wheat milk beverages:}

Moisture, total protein, ash, fat, carbohydrates and energy of cow's milk as a control and three Wheat Milk Beverages (WMB) with difference levels of wheat $(5,10$ and $15 \%)$ are shown in Table (3).

It is noticeable that moisture $(\mathrm{g} / 100 \mathrm{~g}$ wet weight) content was 86.864 $\pm 0.224,84.882 \pm 0.326,84.035 \pm 0.064$ and $83.410 \pm 0.008$ for the control, 5, 10 and 15\% WMB, respectively. Data shows that there were high significant difference $(\mathrm{p}<0.01)$ between the beverages and it was obvious that moisture decreased gradually by increasing the wheat level in the beverage. The same table shows that protein content $(\mathrm{g} / 100 \mathrm{~g} \mathrm{ww})$ was 3.005 $\pm 0.672,3.033 \pm 0.974,3.499 \pm 0.338$ and $3.482 \pm 0.430$ for the control, 5 , 10 and $15 \% \mathrm{WMB}$, respectively. No significant differences were observed in protein values between the control and 5\% WMB; however a significant differences $(\mathrm{p}<0.05)$ were found between the control and $(10-15 \%)$ WMB for the beverages. These results explained that total protein increased by increasing the wheat level in beverages, and that due to increasing the protein level in prepared wheat than cow's milk.

Data represented in Table (3) revealed that there were high significant difference $(p<0.01)$ between the control and three wheat milk beverages in both ash and fat contents for the control. It shows that ash and fat content decreased in three beverages by increasing the wheat level due to the lower content of ash and fat in prepared wheat as compared to cow's milk.

Results in Table (3) show that there were high significant differences $(p<0.01)$ between the control and three beverages in carbohydrate for the beverages, the results show that carbohydrates increased in the beverages by increasing the wheat level and this due to the lower content of carbohydrate in milk as compared to prepared wheat.

The energy values $(\mathrm{k} \mathrm{cal} / 100 \mathrm{~g})$ of WMB were higher than the control. The energy values recorded 70.259 $\pm 2.979,75.113 \pm 8.345,75.611 \pm 0.447$ and $76.635 \pm 0.564$ for the control, 5, 10 and $15 \% \mathrm{WMB}$, respectively. It shows that the control has the lowest energy value and energy values 
increased gradually in the beverages by increasing wheat level because of the higher content of wheat carbohydrates as compared with the milk.

Table (3): Gross chemical composition (g/100g/ww) of wheat milk beverages (WMB).

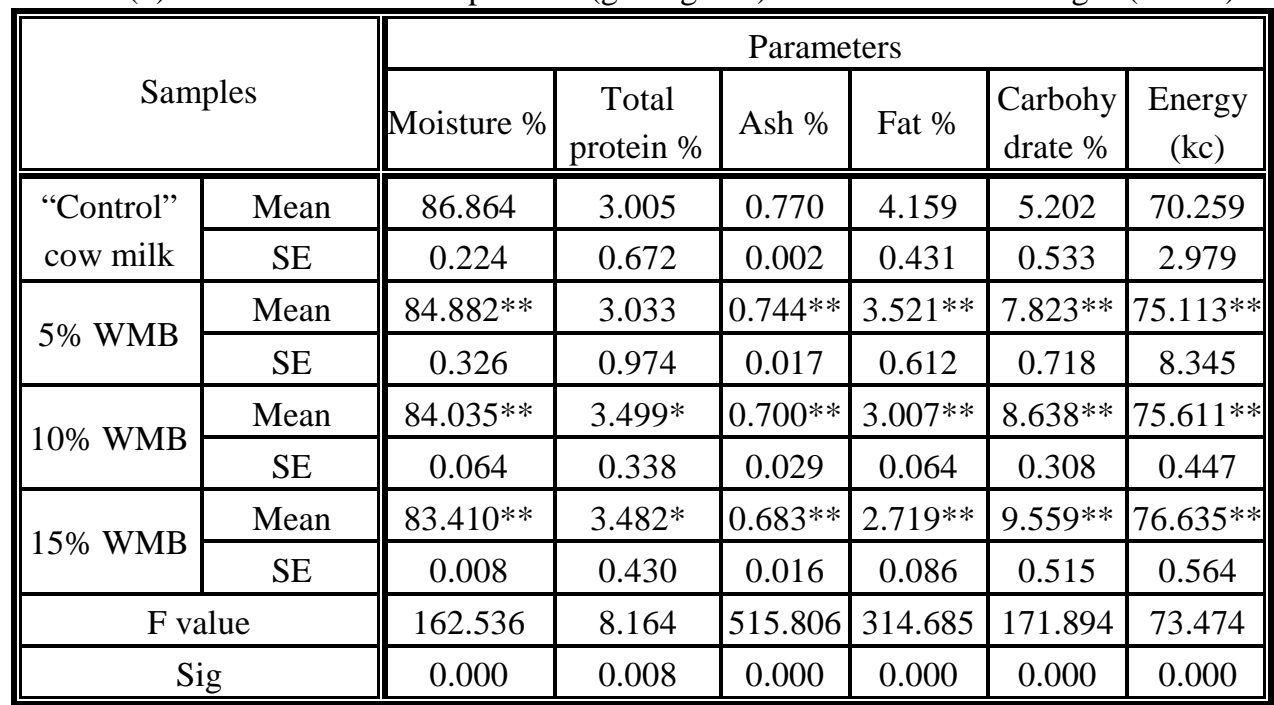

WMB: Wheat Milk Beverage; SE: Standard Error and Mean values in each column having different superscript $(*, * *)$ as $(*)$ indicates the significant difference $(\mathrm{p}<0.05),(* *)$ indicates high significant difference $(\mathrm{p}<0.1)$.

These results agree with those obtained by Yegin and Uren (2008) reported that total dry matters of boza (a fermented beverage made from millet, maize, wheat or rice) samples were from $15.3 \%$ to $31.1 \%(\mathrm{w} / \mathrm{w})$ and protein contents were from $0.50 \%$ to $0.99 \%$ (w/w).

\subsection{Amino acid composition:}

\subsubsection{Amino acids contents of wheat milk beverages (g/100g protein):}

Amino acids play an important role in determining the nutritive value of food stuff protein. Study of amino acids pattern of the control "cow's milk" and wheat milk beverages (WMB), (5\%, $10 \%$ and 15\%) were determined in all amino acids composition of protein except tryptophan. Amino acids calculated as $\mathrm{g} / 100 \mathrm{~g}$ protein. Data in Table (4) shows that total essential amino acids (TEAA) content recorded 39.66, 35.94, 35.12, and $39.91 \mathrm{~g} / 100 \mathrm{~g}$ protein for the control, $5 \%, 10 \%$ and $15 \% \mathrm{WMB}$, respectively, 
however the percentage of essential amino acids (EAA\%) recorded 43.179 $\%, 93.099 \%, 37.926 \%$, and $44.692 \%$ for the control, $5 \%, 10 \%$ and $15 \% \mathrm{WMB}$, respectively. It could be noticed that $15 \% \mathrm{WMB}$ gained the highest values of TEAA and EAA\%; however the lowest value was for $10 \%$ WMB. It is clear from the previous that TEAA and EAA\% scores increased by increasing the wheat contents in the beverage.

Table: (4) Amino acids contents of wheat milk beverages (WMB) g/100g protein.

\begin{tabular}{|c|c|c|c|c|}
\hline Amino acids & Control Cow milk & $5 \% \mathrm{WMB}$ & $10 \% \mathrm{WMB}$ & $15 \% \mathrm{WMB}$ \\
\hline \multicolumn{5}{|c|}{ Essential amino acids: } \\
\hline Threonine & 4.44 & 4.08 & 3.60 & 4.25 \\
\hline Valine & 5.96 & 6.25 & 4.81 & 6.33 \\
\hline Methionine & 2.33 & 1.14 & 0.90 & 0.42 \\
\hline Iso-leucine & 5.12 & 5.50 & 4.30 & 7.28 \\
\hline Leucine & 8.23 & 6.56 & 7.99 & 7.12 \\
\hline Phenylalanine & 4.57 & 4.34 & 4.00 & 5.33 \\
\hline Histidine & 2.33 & 1.77 & 1.40 & 2.38 \\
\hline Lysine & 4.35 & 4.31 & 5.97 & 4.39 \\
\hline Arginine & 2.33 & 1.99 & 2.15 & 2.41 \\
\hline Tryptophan & - & - & - & - \\
\hline TEAA & 39.66 & 35.94 & 35.12 & 39.91 \\
\hline EAA \% & $43.179 \%$ & $39.099 \%$ & $37.926 \%$ & $44.692 \%$ \\
\hline \multicolumn{5}{|c|}{ Non Essential amino acids: } \\
\hline Aspartic & 7.36 & 8.58 & 8.14 & 7.61 \\
\hline Serine & 3.32 & 5.34 & 5.10 & 5.27 \\
\hline Glutamic & 20.12 & 16.66 & 17.22 & 16.75 \\
\hline Proline & 10.62 & 15.95 & 18.01 & 9.23 \\
\hline Glycine & 2.33 & 1.84 & 1.68 & 2.15 \\
\hline Alanine & 3.19 & 3.51 & 3.39 & 3.76 \\
\hline Cystine & 0.53 & 0.13 & 0.39 & 0.08 \\
\hline Tyrosine & 4.72 & 3.97 & 3.55 & 4.54 \\
\hline TNEAA & 52.19 & 55.98 & 57.48 & 49.39 \\
\hline NEAA \% & $56.820 \%$ & $60.900 \%$ & $62.073 \%$ & $55.307 \%$ \\
\hline TAA & 91.85 & 91.92 & 92.6 & 89.3 \\
\hline
\end{tabular}

EAA: Essential Amino Acids; TEAA: Total Essential Amino Acids; TAA: Total Amino Acids; EAA: Non Essential Amino Aids; TNEAA: Total Non Essential Amino Acids and WMB: Wheat Milk Beverage 
The same table shows that total non essential amino acids (TNEAA) recorded 52.19, 55.98, 57.48 and $49.39 \mathrm{~g} / 100 \mathrm{~g}$ protein for the control, 5\%, $10 \%$ and $15 \% \mathrm{WMB}$, respectively, however the percentage of non essential amino acids (NEAA\%) recorded 56.820\%, 60.900\%, 62.073\% and 55.307\% for the control, $5 \%, 10 \%$ and $15 \% \mathrm{WMB}$, respectively. It could be noticed that $10 \%$ WMB gained the highest values of TNEAA and NEAA\%; however 15\% WMB recorded the lowest values. The total amino acid (TAA) had the highest value for $10 \% \mathrm{WMB}$ and the lowest value was for $15 \%$ WMB. These differences in TAA, TNEAA and NEAA\% may be due to the difference in amino acid contents between milk and wheat. These results were in line with Rustom et al. (1996) who reported that the contents of essential amino acids in chocolate-flavored peanut beverage were $(\mathrm{mg} / \mathrm{g}$ protein) cystine + methionine (17), histidine (17), isoleucine (30), leucine (67), lysine (26), threonine (20), tryptophan (13), tyrosine + phenylalanine (69) and valine (35). Also Jiang et al. (2008) found that the mean protein content for wheat-related species (WRS) was $16.67 \%$. The mean contents (g/100 g-1 protein) of most amino acids for WRS were lysine $2.74 \%$, threonine $2.83 \%$, phenylalanine $4.17 \%$, isoleucine $3.42 \%$, valine $3.90 \%$, histidine $2.81 \%$, glutamic acid $29.96 \%$, proline $9.12 \%$, glycine $3.59 \%$, alanine $3.37 \%$, and cysteine $1.57 \%$.

\subsubsection{Essential amino acids of wheat milk beverages compared with hen's egg:}

Data in Table (5) compared essential amino acid (EAA) contents of cow's milk and its products $(5 \%, 10 \%$ and 15\%) wheat milk beverages (WMB) to hen's egg protein as a reference. Data shows that cow's milk, 5\% $\mathrm{WMB}$ and 15\% WMB had a high content of valine as compared to hen's egg protein; however $10 \% \mathrm{WMB}$ had a low content of the same amino acid compared to hen's egg protein. Also it could be noticed that the control, 5\%, $10 \%$ and $15 \% \mathrm{WMB}$ had high content of Iso-leuceine, phenylalanine + tyrosine and therionine as compared to hen's egg protein. Data represented in the same table shows that the control and 10\% WMB had a high content of leucien as compared to hen's egg protein; however 5\% and 15\% WMB 
had a low content of leucien as compared to hen's egg protein. Table (5) also shows that the control, 5\%,10\% and 15\% WMB had a low content of Methionine + cystine as compared to hen's egg protein. Also it could be noticed that 10\% WMB had a high content of lysine, however the control, $5 \% \mathrm{WMB}$ and $15 \% \mathrm{WMB}$ had a low content of the same amino acid as

Table (5): Essential amino acids (EAA) of wheat milk beverages (WMB) compared to hen's egg.

\begin{tabular}{|c|c|c|c|c|c|}
\hline EAA & Hen's egg & $\begin{array}{c}\text { Control } \\
\text { Cow milk }\end{array}$ & $\begin{array}{c}5 \% \\
\text { WMB }\end{array}$ & $\begin{array}{c}10 \% \\
\text { WMB }\end{array}$ & $\begin{array}{c}15 \% \\
\text { WMB }\end{array}$ \\
\hline Valine & 14.687 & 14.807 & 17.227 & 13.545 & 15.928 \\
\hline Iso-leucine & 11.889 & 12.720 & 15.159 & 12.109 & 18.319 \\
\hline Leucine & 18.348 & 20.447 & 18.081 & 22.500 & 17.916 \\
\hline Methionine + Cystine & 11.756 & 7.106 & 3.500 & 3.632 & 1.258 \\
\hline Phenylalanine + Tyrosine & 20.351 & 23.081 & 22.905 & 21.261 & 24.836 \\
\hline Lysine & 13.396 & 10.807 & 11.879 & 16.812 & 11.046 \\
\hline Threonine & 9.572 & 11.031 & 11.245 & 10.137 & 10.694 \\
\hline
\end{tabular}

EAA: Essential Amino Acids. and WMB : Wheat Milk Beverage. El-Sanafiry (1983)

compared to hen's egg protein. These variances in EAA is actually due to the differences levels of wheat which added to cow's milk during processing and its effect in amino acids composition of these beverages.

\subsubsection{Essential amino acids of wheat milk beverages in relative to FAO/WHO protein pattern:}

Essential amino acids of wheat milk beverages (WMB), (5\%, 10\% and 15\%) in relative to FAO/WHO were represented in Table (6). Data shows that cow's milk as a control recorded high contents of leucien + Iso-leucien, phenylalanine + tyrosine, thereonine and valine, however low contents of lysine and methionine + cystine were detected as compared to FAO/WHO protein reference pattern. It could be noticed that 5\% WMB recorded high contents of leucein + Iso-leucein, phenylalanine +tyrosine and valine, however low contents of lysine, methionine + cystine and threonine were detected as compared to FAO/WHO protein reference pattern. On the other hand, data shows that $10 \% \mathrm{WMB}$ recorded high contents of lysine, leucein 
+ Iso-leucein, phenylalanine + tyrosine and valine, however low contents of methionine + cystine and threonine were recorded as compared to $\mathrm{FAO} / \mathrm{WHO}$ protein reference pattern.

Table (6): Essential amino acids (EAA) of wheat milk beverage in relative to $\mathrm{FAO} / \mathrm{WHO}$ protein pattern.

\begin{tabular}{|c|c|c|c|c|c|c|c|c|c|}
\hline EAA & $\begin{array}{c}\text { Scoring } \\
\text { pattern } \\
\text { FAO/ } \\
\text { WHO }\end{array}$ & $\begin{array}{c}\text { Control } \\
\text { Cow } \\
\text { milk }\end{array}$ & $\begin{array}{c}\text { FAO/ } \\
\text { WHO }\end{array}$ & $\begin{array}{c}5 \% \\
\text { WMB }\end{array}$ & $\begin{array}{c}\% \text { from } \\
\text { FAO/ } \\
\text { WHO }\end{array}$ & $\begin{array}{c}10 \% \\
\text { WMB }\end{array}$ & $\begin{array}{c}\% \text { from } \\
\text { FAO/ } \\
\text { WHO }\end{array}$ & $\begin{array}{c}15 \% \\
\text { WMB }\end{array}$ & $\begin{array}{c}\% \text { from } \\
\text { FHO } \\
\text { WHO }\end{array}$ \\
\hline Lysine & 5.50 & 4.35 & 79.091 & 4.31 & 78.363 & 5.97 & 108.545 & 4.39 & 79.818 \\
\hline $\begin{array}{c}\text { Leucien }+ \\
\text { Iso-leucien }\end{array}$ & 11.00 & 13.35 & 121.364 & 12.06 & 109.636 & 12.29 & 111.727 & 14.4 & 130.909 \\
\hline $\begin{array}{c}\text { Methionine }+ \\
\text { Cystine }\end{array}$ & 3.50 & 2.86 & 81.714 & 1.27 & 36.285 & 1.29 & 36.857 & 0.5 & 14.285 \\
\hline $\begin{array}{c}\text { Phenylalanine } \\
+ \text { Tyrosine }\end{array}$ & 6.08 & 9.47 & 155.757 & 8.31 & 136.677 & 7.55 & 124.177 & 9.87 & 162.335 \\
\hline Threonine & 4.40 & 4.44 & 100.909 & 4.08 & 92.727 & 3.60 & 81.818 & 4.25 & 96.590 \\
\hline Valine & 4.69 & 5.96 & 127.079 & 6.25 & 133.262 & 4.81 & 102.558 & 6.33 & 134.968 \\
\hline RAA & & $\begin{array}{r}\text { Methionine }+ \\
\text { Cystine }\end{array}$ & $\begin{array}{r}\text { Methionine }+ \\
\text { Cystine }\end{array}$ & Methionine + & Methionine + \\
Cystine & Cystine \\
\hline
\end{tabular}

EAA: Essential Amino Acids; RAA: Restricting Amino Acids and WMB: Wheat Milk Beverage

Data in Table (6) shows also that 15\% WMB recorded high contents of leucein + Iso-leucein, phenylalanine + tyrosine and valine, however low contents of lysine, methionine + cystine and threonine were found as compared to $\mathrm{FAO} / \mathrm{WHO}$ protein reference pattern. It could be noticed that the control, $5 \%, 10 \%$ and $15 \% \mathrm{WMB}$ had the lowest contents of methionine + cystine as compared to FAO/WHO protein reference pattern. So the first restricting amino acid (RAA) in the control, 5\%, 10\% and 15\% WMB is methionine + cystine. Jiang et al. (2008) evaluated the essential amino acids (EAAS) in wheat-related species (WRS) according to FAO/WHO amino acid recommendations. The materials (Triticum monococcum L., Triticum carthlicum Nevski, and Triticum turgidum L.) contained relatively high 
concentration of the most deficient EAAS (lysine, threonine, and methionine).

\subsubsection{Protein quality of wheat milk beverages:}

The differences of protein quality in cow's milk as a control and (5\%, $10 \%$ and $15 \%$ ) wheat milk beverages (WMB) are shown in Table (7). Data in this table shows that the amino acid score (AAS) values were over 1.0 for all individual essential amino acids (EAA) in the control and (5\%, $10 \%$ and $15 \%) \mathrm{WMB}$ except methionine + cystine in $(5 \%, 10 \%$ and $15 \%) \mathrm{WMB}$ and histadine in $10 \% \mathrm{WMB}$. This indicated that protein of WMB consider a complete protein and have high nutritional value of protein when compared to $\mathrm{FAO} / \mathrm{WHO}$ protein reference pattern, also it could be noticed that $15 \%$ WMB the best beverage due to its recording of the highest ASS value. It could be observed that $10 \%$ WMB obtained the highest protein quality as indicated by the highest value of essential amino acid index (EAAI) and biological value (BV) as compared to the control, 5\% WMB and $15 \%$ WMB, which recorded 92.370 EAAI, 88.954 BV in the control, 85.806 EAAI, 81.799 BV in 5\% WMB, 92.504 EAAI, $89100 \mathrm{BV}$ in 10\% WMB and 87.684 EAAI, $83.846 \mathrm{BV}$ in $15 \%$ WMB. Data shows that protein efficiency ratio (PER)1 values recorded 3.6377, 2.925, 3.4809 and 3.4969 for the control 5\%, 10\% and 15\% WMB, respectively, however (PER)2 values recorded 3.7088, 3.02939, 3.7227 and 3.2237 for the control 5\%, $10 \%$ and $15 \% \mathrm{WMB}$, respectively. It could be observed that the highest PER1 value was for the control followed by $15 \% \mathrm{WMB}$ and the highest PER2 value was for $10 \% \mathrm{WMB}$ followed by the control. So these results indicated that $(15 \%$ and $10 \%) \mathrm{WMB}$ were expected to be easier digested that 5\% WMB according to PER1 and PER2 values. These results were in line with Jiang et al. (2008) who evaluated the essential amino acids (EAAs) of wheat-related species (WRS) in comparing with FAO/WHO amino acid recommendations, they found that the amino acid scores (AAS) of lysine (49.8\%), threonine (70.7\%). and sulfur-containing amino acids (74.8\%) were the lowest, which were considered as the main limiting amino acids in WRS. 
1.3. Sensory evaluation of wheat milk beverages:

Average of organoleptic scores recorded in cow's milk (the control) and its treatments $(5 \%, 10 \%$ and $15 \%)$ wheat milk beverages (WMB) are presented in Table (8). It could be noticed that no significant differences were detected in color between the control and (5\%, 10\% and 15\%) WMB. The highest color value was for both the control $8.00 \pm 0.258$, followed by $15 \%$ WMB which recorded $8.00 \pm 0.000$, then $5 \%$ WMB $7.800 \pm 0.133$, then $10 \%$ WMB $7.600 \pm 0.163$. No significant differences were detected in texture between the control and (5\%,10\% and 15\%) WMB. Data recorded $(8.00 \pm 0.471,7.200 \pm 0.133,8.00 \pm 0.298$ and $8.200 \pm 0.133)$ for the control and (5\%, 10\% and 15\%) WMB, respectively. 15\% WMB gained the highest texture value, followed by both the control and 10\% WMB which gained the same mean value (8.00) then the lowest value was for 5\% WMB. Data shows that there were no significant differences in taste between the control and (5\% - 10\%) WMB, however there were high significant differences $(p<0.01)$ between the control and 15\% WMB for wheat beverage which recorded the highest taste $8.400 \pm 0.163$, however the lowest taste was for 5\% WMB. Data obtained from Table (8) shows that 15\% WMB gained the highest odor and the lowest odor, however was for the control, however (5\% and $10 \%$ ) WMB recorded the same value. 
Table (7): Protein quality (mg) of wheat milk beverages (WMB).

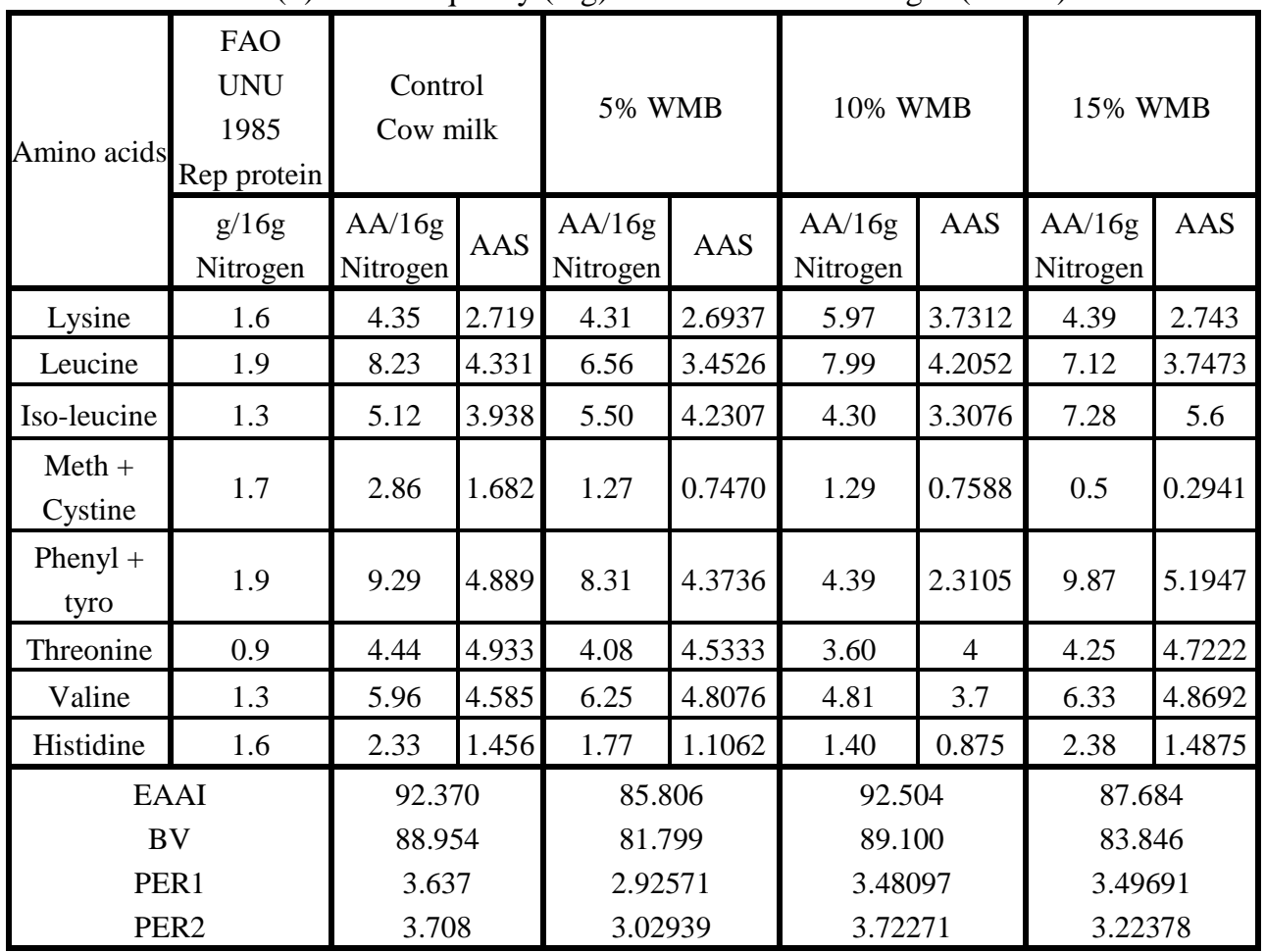

AAS: Amino Acid Score; PER: Protein Efficiency Ratio; EAAI: Essential Amino Acid Index; BV: Biological Value and WMB: Wheat Milk Beverage.

Table (8): Organoleptic properties of wheat milk beverages (WMB)

\begin{tabular}{|c|c|c|c|c|c|c|}
\hline \multirow{2}{*}{ Samples } & \multicolumn{5}{c|}{ Parameters } \\
\cline { 2 - 7 } & Color & Texture & Taste & Odor & Overall acceptability \\
\hline \multirow{2}{*}{$\begin{array}{c}\text { "Control" } \\
\text { cow milk }\end{array}$} & Mean & 8.00 & 8.00 & 7.300 & 7.600 & 7.725 \\
\cline { 2 - 7 } & SE & 0.258 & 0.471 & 0.335 & 0.163 & 0.306 \\
\hline \multirow{2}{*}{$5 \%$ WMB } & Mean & 7.800 & 7.200 & 7.200 & 7.800 & 7.500 \\
\cline { 2 - 7 } & SE & 0.133 & 0.133 & 0.249 & 0.249 & 0.191 \\
\hline \multirow{2}{*}{$10 \%$ WMB } & Mean & 7.600 & 8.00 & 7.600 & 7.800 & 7.750 \\
\cline { 2 - 7 } & SE & 0.163 & 0.298 & 0.266 & 0.249 & 0.244 \\
\hline \multirow{2}{*}{$15 \%$ WMB } & Mean & 8.00 & 8.200 & $8.400 * *$ & 8.200 & 8.200 \\
\cline { 2 - 7 } & SE & 0.000 & 0.133 & 0.163 & 0.249 & 0.249 \\
\hline \multicolumn{2}{|c|}{ F value } & 1.320 & 2.269 & 4.347 & 1.187 & 4.034 \\
\hline \multicolumn{2}{|c|}{ Sig } & 0.283 & 0.097 & 0.010 & 0.328 & 0.14 \\
\hline
\end{tabular}

WMB: Wheat Milk Beverage; SE: Standard Error and Mean values in each column having different superscript $(* *)$ as $(* *)$ indicates high significant difference $(\mathrm{p}<0.1)$. 
Data represented in the same table also shows that overall acceptability recorded $7.725 \pm 0.306,7.500 \pm 0.191,7.750 \pm 0.244$ and $8.200 \pm 0.249$ for the control, $5 \%, 10 \%$ and $15 \%$ wheat milk beverages, respectively. Data shows that $15 \%$ WMB gained the highest value mean while; the control recorded the lowest value. Finally, it could be noticed from Table (8) that 15\% WMB recorded the highest score in color, texture, taste, odor and overall acceptability. Milk-based beverages are increasing in popularity in the United States and other parts of the world. Modified milks refer to milk-based beverages in which fluid milk is altered to deliver a more comprehensive nutritional composition and, in some cases, to enhance flavor, digestion, and functionality (Guo, 2011).

\section{Fruit \& chocolate wheat milk beverages:}

\subsection{Chemical composition:}

Moisture, total protein, ash, fat, carbohydrate and energy of wheat milk beverages with $(5 \%, 10 \%$ and $15 \%)$ fruit $\&$ chocolate are recorded in Tables $(9,10$ and 11).

\subsubsection{Gross chemical composition $(\mathrm{g} / 100 \mathrm{~g} / \mathrm{ww})$ of strawberry wheat milk beverages:}

Moisture, total protein, ash, fat, carbohydrate and energy of $15 \%$ wheat milk beverage as a control and three wheat milk beverages with a different levels of strawberry (5, 10 and 15\%) are recorded in Table (9).

There were high significant differences $(\mathrm{p}<0.01)$ between the control and strawberry wheat milk beverages (SWMB) in the moisture content for the beverages which recorded $83.410 \pm 0.008,85.925 \pm 0.037,85.320 \pm$ 0.019 and $85.554 \pm 0.086$ for the control, 5, 10 and 15\% SWMB, respectively. This result due to the higher moisture content of strawberry beverages as compared to wheat milk beverage.

Data shows that there were significant differences $(\mathrm{p}<0.05)$ between the control and $(5,10$ and 15\%) SWMB in total protein and fat content for the control; however there were high significant differences $(p<0.01)$ between them in ash and carbohydrate for the control also, and this due to 
the higher content of ash, protein and carbohydrate of the control as compared to strawberry beverages.

Data represented in Table (9) shows that there were high significant differences $(\mathrm{p}<0.01)$ between the control and SWMB in the energy values for the control which recorded $76.635 \pm 0.564,66.539 \pm 0.740,69.558 \pm$ 0.803 and $67.434 \pm 0.701$ for the control, 5, 10 and 15\% SWMB respectively and this due to the lower content of fat, protein and carbohydrates for the beverages as compared to the control.

These results were in agreement with Johnson et al. (2002) who stated that flavored milks offer a well-accepted, nutritious alternative in the wide array of beverages available to children in the United States. Also Nebot et al. (2010) found that the addition of milk to fruit beverages exerted a positive effect on iron retention, transport and uptake versus fruit beverages, and this effect was greater than that of caseinophosphopeptides (CPPs) added to soluble fractions of fruit beverages. The addition of CPPs to soluble fractions of fruit beverages improved iron transport. Iron supplementation increased $\mathrm{Fe}$ retention, transport and uptake - the effect being more notable in samples with milk.

\subsubsection{Gross chemical composition (g/100g/ww) of mango wheat milk beverages:}

Data represented in Table (10) shows the moisture, total protein, ash, fat, carbohydrate and energy of $15 \%$ wheat milk beverage as a control and three wheat milk beverages with a different levels of mango (5, 10 and $15 \%)$.

High significant differences $(\mathrm{p}<0.01)$ were found between the control and three mango wheat milk beverages (MWMB) for the control in ash contents due to the higher contents of ash for the control as compared to MWMB, however high significant differences $(\mathrm{p}<0.01)$ were found between the control and three MWMB for the beverages in moisture due to the higher contents of moisture for MWMB as compared to wheat milk beverages; however there were no significant differences between the 
control and MWMB in protein which recorded 3.482 $\pm 0.430,3.307 \pm$ $2.241,2.946 \pm 3.157$ and $2.200 \pm 1.578$ for the control, 5, 10 and $15 \%$ MWMB, respectively.

Results in Table (10) shows that no significant differences were found between the control, 5, 10 and 15\% MWMB in carbohydrate contents which recorded $9.559 \pm 0.515,7.639 \pm 1.798,9.025 \pm 1.157$ and $10.738 \pm 1.887$ for the control, 5, 10 and 15\% MWMB, respectively.

Data also shows that there were no significant differences in energy values between the control and three mango beverages. The highest energy value was for the control which recorded $76.635 \pm 0.564$ due to its higher content of fat and protein as compared with other beverages. The lowest energy value was for 5\% MWMB due to lower contents of fat and protein as compared with other beverages.

These results were in line with Policegoudra and Aradhya (2008) who mentioned that the mango ginger contains $1.3 \%$ ash, $9.8 \%$ moisture and $45 \%$ starch with $43 \%$ amylose. Flavored milks can play a role in changing recent trends in children's sugar-sweetened beverage consumption patterns that have a negative impact on their diet quality (Johnson et al., 2002).

\subsubsection{Gross chemical composition (g/100g/ww) of chocolate wheat milk beverages:}

Data concerning the chemical composition, moisture, total protein, ash, fat, carbohydrates content and energy of $15 \%$ wheat milk beverage as a control and three wheat milk beverage with a different levels of chocolate $(5,10$ and $15 \%)$ are recorded in Table (11).

Moisture $(\mathrm{g} / 100 \mathrm{~g})$ content was $16.589 \pm 0.008,19.404 \pm 0.212,23.203$ \pm 0.032 and $27.711 \pm 0.012$ for the control, 5,10 and $15 \%$ Chocolate Wheat Milk Beverages (CWMB), respectively. Data shows that there were high significant difference $(\mathrm{p}<0.01)$ between the control and $(5,10$ and 15\%) CWMB for the control and it was obvious that total solid increased by increasing the chocolate level. 
It could be noticed from the same table that protein content $(\mathrm{g} / 100 \mathrm{~g})$ was $3.482 \pm 0.430,3.863 \pm 0.189,4.746 \pm 0.063$ and $5.304 \pm 0.631$ for the control, 5, 10 and 15\% CWMB, respectively. In protein content no significant differences were observed between the control and (5 or 10\%) CWMB; however there was a significant difference $(p<0.05)$ between the control and 15\% CWMB for the chocolate beverage, this due to the higher content of protein in chocolate powder as compared to wheat milk beverage. So the protein value increased by increasing chocolate values in beverages.

Data represented in Table (11) shows that there were high significant differences $(p<0.01)$ between the control and chocolate beverages in ash and fat contents $(\mathrm{g} / 100 \mathrm{~g})$ for the beverages. It shows that ash and fat content increased in 5,10 and 15\% CWMB by increasing the chocolate powder level due to the higher content of ash and fat in chocolate powder as compared to the control.

No significant differences were detected between the control and three chocolate beverages in the carbohydrates content which recorded $9.559 \pm$ $0.515,11.723 \pm 0.544,14.713 \pm 0.379$ and $18.344 \pm 0.876$ for the control, 5 , 10 and $15 \%$ CWMB, respectively.

The same table shows that there were high significant differences $(p<0.01)$ between the control and three chocolate beverages in energy values (kcal / 100g) for the beverages. Results in Table (11) indicate that the energy values were $76.635 \pm 0.564,90.082 \pm 0.867,103.792 \pm 1.119$ and $122.599 \pm 1.198$ for the control and chocolate beverages $(5,10$ and $15 \%)$, respectively. It shows that $15 \% \mathrm{CWMB}$ has the highest energy value because of its higher content of fat, protein and carbohydrates.

These results were in line with Rustom et al. (1996) who reported that the chocolate-flavored peanut beverage contained (g/100 $\mathrm{g}$ beverage) protein (3.0), fat (5.2) and carbohydrates (9.6). Also results agree with those obtained by Miller et al. (2007) who stated that chocolate milk has high protein content and is a good source of vitamins, calcium and other nutrients; and USDA (2008) who reported that servings of plain milk and 
chocolate milk provide essentially identical amounts of protein, total and saturated fat, calcium, phosphorus, magnesium, vitamin A, riboflavin, and potassium. Also Yanes et al. (2002) mentioned that the particular characteristics of the different ingredients - fat content of milk, alcalinity and color of cocoa powder- should produce noticeable differences in the final composition and in the specific physical and sensory properties of the formulated products.

\subsection{Sensory evaluation:}

Average of organoleptic scores recorded in wheat milk beverages with (5\%, 10\% and 15\%) fruit \& chocolate are recorded in Tables (12, 13 and 14).

\subsubsection{Organoleptic properties of strawberry wheat milk beverages:}

Average of organoleptic scores recorded in wheat milk beverage (the control) and its treatments $(5 \%, 10 \%$ and 15\%) strawberry wheat milk beverages (SWMB) are presented in Table (12). High Significant differences $(\mathrm{p}<0.01)$ were found between the control and $(5 \%-15 \%)$ SWMB in color for the beverages, however no significant differences were detected between the control and 10\% SWMB. Data in the same table shows that no significant differences were detected between the control and $(5 \%$, $10 \%$ and $15 \%)$ SWMB in texture which recorded $8.200 \pm 0.133,8.400 \pm$ $0.163,8.400 \pm 0.163$ and $7.900 \pm 0.276$ for the control, $5 \%, 10 \%$ and $15 \%$ SWMB, respectively. The highest values were for (5\% and 10\%) SWMB, however the lowest value was for $15 \%$ SWMB. Significant differences $(\mathrm{p}<0.05)$ were observed between the control and 5\% SWMB in taste for SWMB, however there were no significant differences in taste between the control and (10\% - 15\%) SWMB. Data in Table (12) shows that high significant differences $(\mathrm{p}<0.01)$ were found between the control and $5 \%$ SWMB in overall acceptability, however no significant differences were observed between the control 


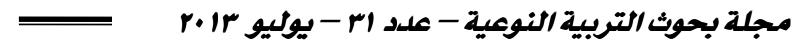

Table (9): Gross chemical composition (g/100g/ww) of strawberry wheat milk beverages (SWMB).

\begin{tabular}{|c|c|c|c|c|c|c|c|}
\hline \multirow{2}{*}{\multicolumn{2}{|c|}{$\frac{\text { Parameters }}{\text { Beverages }}$}} & \multirow{3}{*}{$\begin{array}{c}\text { Moisture } \\
\% \\
83.410 \\
\end{array}$} & \multirow{3}{*}{$\begin{array}{c}\begin{array}{c}\text { Total } \\
\text { protein } \%\end{array} \\
3.482 \\
\end{array}$} & \multirow{3}{*}{$\begin{array}{c}\text { Ash \% } \\
0.830 \\
\end{array}$} & \multirow{3}{*}{$\begin{array}{l}\text { Fat } \% \\
2.719 \\
\end{array}$} & \multirow{3}{*}{\begin{tabular}{|c|}
$\begin{array}{c}\text { Carbohydrat } \\
\text { e \% }\end{array}$ \\
9.559 \\
\end{tabular}} & \multirow{3}{*}{$\begin{array}{c}\text { Energy }(\mathrm{kc}) \\
76.635 \\
\end{array}$} \\
\hline & & & & & & & \\
\hline \multirow{2}{*}{$\begin{array}{c}\text { "Control" } \\
\text { WMB }\end{array}$} & Mean & & & & & & \\
\hline & SE & 0.008 & 0.430 & 0.016 & 0.086 & 0.515 & 0.564 \\
\hline \multirow{2}{*}{$5 \%$ SWMB } & Mean & $85.925^{* *}$ & $3.354 *$ & $0.624 * *$ & $2.547 *$ & $7.55 * *$ & $66.539 * *$ \\
\hline & SE & 0.037 & 0.304 & 0.012 & 0.129 & 0.230 & 0.740 \\
\hline \multirow{2}{*}{$10 \%$ SWMB } & Mean & $85.320 * *$ & $3.002 *$ & $0.643 * *$ & $2.682 *$ & $8.353 * *$ & $69.558 * *$ \\
\hline & SE & 0.019 & 1.588 & 0.045 & 0.130 & 1.508 & 0.803 \\
\hline \multirow{2}{*}{$15 \%$ SWMB } & Mean & $85.554 * *$ & $2.581 *$ & $0.690^{* *}$ & $2.482 *$ & $8.693 * *$ & $67.434 * *$ \\
\hline & SE & 0.086 & 0.031 & 0.043 & 0.080 & 0.040 & 0.701 \\
\hline \multicolumn{2}{|c|}{ F value } & 557.436 & 31.792 & 71.607 & 75.769 & 29.411 & 194.969 \\
\hline \multicolumn{2}{|l|}{ Sig } & 0.000 & 0.000 & 0.000 & 0.000 & 0.000 & 0.000 \\
\hline
\end{tabular}

Table (10): Gross chemical composition (g/100g/ww) of mango wheat milk beverages (MWMB).

\begin{tabular}{|c|c|c|c|c|c|c|c|}
\hline \multicolumn{2}{|c|}{ Parameters } & \multirow{2}{*}{$\begin{array}{c}\text { Moisture } \\
\%\end{array}$} & \multirow{2}{*}{$\begin{array}{c}\text { Total } \\
\text { protein } \\
\%\end{array}$} & \multirow{2}{*}{ Ash \% } & \multirow{2}{*}{ Fat $\%$} & \multirow{2}{*}{$\begin{array}{c}\text { Carbohy } \\
\text { drate \% }\end{array}$} & \multirow{2}{*}{ Energy $(\mathrm{kc})$} \\
\hline \multicolumn{2}{|c|}{ Beverages } & & & & & & \\
\hline \multirow{2}{*}{$\begin{array}{c}\text { "Control" } \\
\text { WMB }\end{array}$} & Mean & 83.410 & 3.482 & 0.830 & 2.719 & 9.559 & 76.635 \\
\hline & SE & 0.008 & 0.430 & 0.016 & 0.086 & 0.515 & 0.564 \\
\hline \multirow{2}{*}{$\begin{array}{c}5 \% \\
\text { MWMB }\end{array}$} & Mean & $85.285^{* *}$ & 3.307 & $0.597 * *$ & 3.172 & 7.639 & 72.332 \\
\hline & SE & 0.030 & 2.241 & 0.012 & 0.630 & 1.798 & 2.28 \\
\hline \multirow{2}{*}{$\begin{array}{c}10 \% \\
\text { MWMB }\end{array}$} & Mean & $84.609 * *$ & 2.946 & $0.589 * *$ & 2.831 & 9.025 & 73.363 \\
\hline & SE & 0.044 & 1.157 & 0.050 & 1.035 & 1.157 & 1.514 \\
\hline \multirow{2}{*}{$\begin{array}{c}15 \% \\
\text { MWMB }\end{array}$} & Mean & $83.908 * *$ & 2.200 & $0.573 * *$ & 2.581 & 10.738 & 74.981 \\
\hline & SE & 0.124 & 1.578 & 0.023 & 0.467 & 1.887 & 1.929 \\
\hline \multicolumn{2}{|c|}{ F value } & 145.325 & 3.354 & 457.213 & 4.004 & 4.697 & 4.335 \\
\hline \multicolumn{2}{|c|}{ Sig } & 0.000 & 0.076 & 0.000 & 0.052 & 0.036 & 0.043 \\
\hline
\end{tabular}


Table (11): Gross chemical composition (g/100g/ww) of chocolate wheat milk beverage (CWMB).

\begin{tabular}{|c|c|c|c|c|c|c|c|}
\hline \multicolumn{2}{|c|}{ Parameters } & \multirow{2}{*}{$\begin{array}{c}\text { Moisture } \\
\%\end{array}$} & \multirow{2}{*}{$\begin{array}{c}\text { Total } \\
\text { protei } \\
\text { n } \%\end{array}$} & \multirow{2}{*}{ Ash \% } & \multirow{2}{*}{ Fat $\%$} & \multirow{2}{*}{$\begin{array}{c}\text { Carbo } \\
\text { hydrat } \\
\text { e } \%\end{array}$} & \multirow{2}{*}{ Energy (kc) } \\
\hline \multicolumn{2}{|c|}{ Beverages } & & & & & & \\
\hline \multirow{2}{*}{$\begin{array}{c}\text { "Control" } \\
\text { WMB }\end{array}$} & Mean & 83.410 & 3.482 & 0.830 & 2.719 & 9.559 & 76.635 \\
\hline & SE & 0.008 & 0.430 & 0.016 & 0.086 & 0.515 & 0.564 \\
\hline \multirow{2}{*}{$5 \%$ CWMB } & Mean & $80.596^{* *}$ & 3.863 & $0.736^{* *}$ & 3.082 & 11.723 & $90.082^{* *}$ \\
\hline & SE & 0.212 & 0.189 & 0.027 & 0.251 & 0.544 & 0.867 \\
\hline \multirow{2}{*}{$\begin{array}{c}10 \% \\
\text { CWMB }\end{array}$} & Mean & $76.796^{* *}$ & 4.746 & $0.861 * *$ & $2.884 * *$ & 14.713 & $103.792 * *$ \\
\hline & $\mathrm{SE}$ & 0.032 & 0.063 & 0.103 & 0.248 & 0.379 & 1.119 \\
\hline \multirow{2}{*}{$\begin{array}{c}15 \% \\
\text { CWMB }\end{array}$} & Mean & $72.288 * *$ & $5.304 *$ & $0.941 * *$ & $3.123 * *$ & 18.344 & $122.599 * *$ \\
\hline & SE & 0.012 & 0.631 & 0.053 & 0.277 & 0.876 & 1.198 \\
\hline \multicolumn{2}{|c|}{ F value } & 1.999 & 4.009 & 137.618 & 119.925 & 3.870 & 915.861 \\
\hline \multicolumn{2}{|c|}{ Sig } & 0.000 & 0.052 & 0.000 & 0.000 & 0.056 & 0.000 \\
\hline
\end{tabular}

WMB: Wheat Milk Beverage; SWMB: Strawberry Wheat Milk Beverage; MWMB: Mango Wheat Milk Beverage, CWMB: Chocolate Wheat Milk Beverage; SE: Standard Error and Mean values in each column having different superscript $(*, * *)$ as $(*)$ indicates the significant difference $(\mathrm{p}<0.05),(* *)$ indicates high significant difference $(\mathrm{p}<0.1)$.

and (10\% - 15\%) SWMB. Overall, it could be noticed from Table (12) that 5\% SWMB gained the highest score in color, texture, taste, odor and overall acceptability. These results were in harmony with Bisig (2011) who stated that flavored milks are unfermented milks mixed with sugar, a flavor/aroma-giving ingredient, and stabilizers. They cater to the desire of the consumers, especially children, for variety and a different experience in flavor. Important flavors are chocolate, coffee, vanilla, strawberry, malt extract and chocolate, and banana. Also Kosikowski (1969) found that strawberry- flavored buttermilk was the preferred beverage among five different flavored buttermilks. Strawberry flavored milk demonstrates high acceptability with the consumer (Miller et al., 2007). 


\subsubsection{Organoleptic properties of mango wheat milk beverages:}

Average of organoleptic scores of in wheat milk beverage (the control) and its treatments (5\%, 10\% and 15\%) mango wheat milk beverages $(\mathrm{MWMB})$ are presented in Table $(13)$. Significant differences $(\mathrm{p}<0.05)$ were found between the control and (5\% - 10\%) MWMB in color for the mango beverages, however high significant differences $(\mathrm{p}<0.01)$ were detected between the control and 15\% MWMB for the mango beverage. Data shows that there were significant differences $(p<0.05)$ in texture between the control and 5\% MWMB for the mango beverage, however high significant differences $(\mathrm{p}<0.01)$ were observed in texture between the control and $15 \%$ MWMB for the control. No significant differences were detected between the control and 10\% MWMB. There was high significant differences $(\mathrm{p}<0.01)$ between the control and 5\% MWMB in taste for the mango beverage, however significant differences $(\mathrm{p}<0.05)$ were observed between the control and 15\% MWMB in taste also for the control. No significant differences were noticed between the control and 10\% MWMB. Data represented in the same table shows high significant differences $(p<0.01)$ between the control and 5\% MWMB in odor and overall acceptability for $5 \% \mathrm{MWMB}$, however there were no significant differences between the control and (10\% - 15\%) MWMB. Overall, it could be noticed from Table (13) that 5\% MWMB gained the highest score in texture, taste, odor and overall acceptability. These results were in line with Policegoudra and Aradhya (2008) who mentioned that due to mango ginger exotic flavor and medicinal property, they are used in the preparation of special foods, beverages and pharmaceutical and cosmetic industries. Sugar-sweetened beverages such as soft drinks and fruit drinks provide significant proportions of daily energy and added sugars intakes, and fruit drinks make small contributions to vitamin C intakes (Subar et al., 1998 and Murphy et al., 2005). They also reported that fruit juices are top contributors to intakes of vitamin $\mathrm{C}$ and folate. 


\subsubsection{Organoleptic properties of chocolate wheat milk beverages:}

Average of organoleptic scores of wheat milk beverage (the control) and its treatments $(5 \%, 10 \%$ and 15\%) chocolate wheat milk beverages (CWMB) are presented in Table (14). Data shows that there were no significant differences between the control, 5\%, 10\% and 15\% CWMB in color which recorded $8.000 \pm 0.000,7.900 \pm 0.100,7.600 \pm 0.221$ and 8.200 \pm 0.200 for the control $5 \%, 10 \%$ and $15 \% \mathrm{CWMB}$, respectively. The highest color score was for $15 \% \mathrm{CWMB}$ and the lowest color score was for $10 \%$ CWMB. There were significant differences $(\mathrm{p}<0.05)$ between the control and $15 \% \mathrm{CWMB}$ in texture for the control, however no significant differences were found between the control and (5\% - 10\%) CWMB. Significant differences were found between the control and three chocolate beverages in taste which recorded $(8.400 \pm 0.163,8.200 \pm 0.133,8.500$ \pm 0.166 and $8.600 \pm 0.371$ ) for the control, 5\%, 10\% and 15\% CWMB, respectively. The highest score was for $15 \% \mathrm{CWMB}$ and the lowest score was for 5\% CWMB. Data shows that odor scores were $(8.200 \pm 0.249$, $8.300 \pm 0.260,8.800 \pm 0.133$ and $8.00 \pm 0.258$ ) for the control, $5 \%, 10 \%$ and $15 \%$ CWMB respectively. 10\% CWMB gained the highest score in odor; however the lowest odor score was for $15 \%$ CWMB. Significant differences $(\mathrm{p}<0.05)$ were detected between the control and 10\% CWMB in the overall acceptability for the chocolate beverage, however no significant differences between the control and (5\% - 15\%) From Table (14) it could be concluded that $10 \%$ CWMB gained the highest score in texture, taste, odor and overall acceptability. These results were in line with Miller et al. (2007) who stated that chocolate milk is the most popular flavored milk, especially with children ( $90 \%$ like its taste). Chocolate was the preferred flavor of flavored milk of strawberry yogurt, vanilla pudding, and chocolate ice cream (Johnson et al., 2002). Also Rustom et al. (1996) reported that aroma and taste mean scores of chocolate-flavored peanut beverage were (4.2/5) and (3.8/5), respectively, and correlated with acceptability (5.4/7). Flavored products are the most popular ones. Basically, they are formulated with milk, sucrose, cocoa powder and some hydrocolloids, added to improve consistency and prevent sedimentation of cocoa particles (Yanes et al., 2002). 
Table (12): Organoleptic properties of strawberry wheat milk beverages (SWMB).

\begin{tabular}{|c|c|c|c|c|c|c|}
\hline \multicolumn{2}{|c|}{ Parameters } & Color & Texture & Taste & Odor & $\begin{array}{c}\text { Overall } \\
\text { acceptability }\end{array}$ \\
\hline \multirow{2}{*}{$\begin{array}{c}\text { Beverages } \\
\text { Wontrol" }\end{array}$} & Mean & 8.00 & 8.200 & 8.400 & 8.200 & 8.200 \\
\cline { 2 - 6 } & SE & 0.000 & 0.133 & 0.163 & 0.249 & 0.249 \\
\hline \multirow{2}{*}{$5 \%$ SWMB } & Mean & $8.800^{* *}$ & 8.400 & $9.100^{*}$ & $8.800^{* *}$ & $8.775^{* *}$ \\
\cline { 2 - 7 } & SE & 0.249 & 0.163 & 0.276 & 0.133 & 0.205 \\
\hline \multirow{2}{*}{$5 \%$ SWMB } & Mean & 8.400 & 8.400 & 8.100 & 8.400 & 8.325 \\
\cline { 2 - 6 } & SE & 0.266 & 0.163 & 0.233 & 0.305 & 0.241 \\
\hline \multirow{2}{*}{$10 \%$ SWMB } & Mean & $8.800 * *$ & 7.900 & 7.800 & 7.400 & 7.975 \\
\cline { 2 - 6 } & SE & 0.133 & 0.276 & 0.249 & 0.163 & 0.205 \\
\hline \multicolumn{2}{|c|}{ F value } & 3.882 & 1.511 & 5.636 & 8.686 & 8.574 \\
\hline \multicolumn{2}{|c|}{ Sig } & 0.017 & 0.228 & 0.003 & 0.000 & 0.000 \\
\hline
\end{tabular}

Table (13): Organoleptic properties of mango wheat milk beverages (MWMB).

\begin{tabular}{|c|c|c|c|c|c|c|}
\hline \multicolumn{2}{|c|}{ Parameters } & \multirow{2}{*}{ Color } & \multirow{2}{*}{ Texture } & \multirow{2}{*}{ Taste } & \multirow{2}{*}{ Odor } & \multirow{2}{*}{$\begin{array}{c}\text { Overall } \\
\text { acceptability }\end{array}$} \\
\hline \multicolumn{2}{|c|}{ Beverages } & & & & & \\
\hline \multirow{2}{*}{$\begin{array}{c}\text { "Control" } \\
\text { WMB }\end{array}$} & Mean & 8.00 & 8.200 & 8.400 & 8.200 & 8.200 \\
\hline & SE & 0.000 & 0.133 & 0.163 & 0.249 & 0.249 \\
\hline \multirow{2}{*}{$5 \%$ MWMB } & Mean & $8.600 *$ & $8.800 *$ & $9.200 * *$ & $9.200 * *$ & $8.950 * *$ \\
\hline & SE & 0.163 & 0.133 & 0.200 & 0.249 & 0.210 \\
\hline \multirow{2}{*}{$5 \%$ MWMB } & Mean & $8.600 *$ & 8.200 & 8.200 & 8.00 & 8.250 \\
\hline & SE & 0.305 & 0.290 & 0.200 & 0.210 & 0.251 \\
\hline \multirow{2}{*}{$10 \%$ MWMB } & Mean & $8.800 * *$ & $7.200 * *$ & $7.800 *$ & 7.800 & 7.900 \\
\hline & SE & 0.133 & 0.249 & 0.249 & 0.133 & 0.191 \\
\hline \multicolumn{2}{|c|}{$F$ value } & 3.484 & 9.659 & 8.211 & 8.286 & 4.800 \\
\hline \multicolumn{2}{|l|}{ Sig } & 0.026 & 0.000 & 0.000 & 0.000 & 0.006 \\
\hline
\end{tabular}


Table (14): Organoleptic properties of chocolate wheat milk beverage.

\begin{tabular}{|c|c|c|c|c|c|c|}
\hline \multirow{2}{*}{\multicolumn{2}{|c|}{$\begin{array}{c}\text { Parameters } \\
\text { Beverages }\end{array}$}} & \multirow{3}{*}{$\frac{\text { Color }}{8.00}$} & \multirow{3}{*}{$\begin{array}{c}\text { Texture } \\
8.200 \\
\end{array}$} & \multirow{3}{*}{$\frac{\text { Taste }}{8.400}$} & \multirow{3}{*}{$\frac{\text { Odor }}{8.200}$} & \multirow{3}{*}{$\begin{array}{c}\begin{array}{c}\text { Overall } \\
\text { acceptability }\end{array} \\
8.200\end{array}$} \\
\hline & & & & & & \\
\hline \multirow{2}{*}{$\begin{array}{c}\text { "Control" } \\
\text { WMB }\end{array}$} & Mean & & & & & \\
\hline & $\mathrm{SE}$ & 0.000 & 0.133 & 0.163 & 0.249 & 0.249 \\
\hline \multirow{2}{*}{$5 \%$ CWMB } & Mean & 7.900 & 8.200 & 8.200 & 8.300 & 8.150 \\
\hline & SE & 0.100 & 0.133 & 0.133 & 0.260 & 0.156 \\
\hline \multirow{2}{*}{$5 \%$ CWMB } & Mean & 7.600 & 8.300 & 8.500 & 8.800 & $8.300 *$ \\
\hline & $\mathrm{SE}$ & 0.221 & 0.260 & 0.166 & 0.133 & 0.195 \\
\hline \multirow{2}{*}{$10 \% \mathrm{CWMB}$} & Mean & 8.200 & $7.600 *$ & 8.600 & 8.00 & 8.100 \\
\hline & SE & 0.200 & 0.163 & 0.371 & 0.258 & 0.248 \\
\hline \multicolumn{2}{|c|}{ F value } & 2.528 & 3.164 & 0.556 & 2.161 & 4.324 \\
\hline \multicolumn{2}{|c|}{ Sig } & 0.073 & 0.036 & 0.648 & 0.110 & 0.011 \\
\hline
\end{tabular}

WMB: Wheat Milk Beverage; SWMB: Strawberry Wheat Milk Beverage; MWMB: Mango Wheat Milk Beverage, CWMB: Chocolate Wheat Milk Beverage; SE: Standard Error and Mean values in each column having different superscript $(*, * *)$ and $(*)$ indicates the significant difference $(\mathrm{p}<0.05),(* *)$ indicates high significant difference $(\mathrm{p}<0.1)$.

\subsection{Physical properties of selected fruit \& chocolate wheat milk beverages:}

Values of viscosity, total soluble solids (TSS), pectin, color, and $\mathrm{pH}$ in $15 \%$ wheat milk beverage (WMB) the control and its treatments $5 \%$ strawberry wheat milk beverage (SWMB), 5\% mango wheat milk beverage (MWMB) and 10\% chocolate wheat milk beverage (CWMB) are presented in Table (15). Data shows that viscosity values recorded 36.00, 40.00, 45.00 and 30.00 for the control, CWMB. 5\% SWMB, 5\% MWMB and 10\% CWMB, respectively. Data shows that TSS recorded

13.5, 10.5, 12.5 and 19.0 for the control, 5\% SWMB, 5\% MWMB and $10 \%$ CWMB, respectively. It could be noticed that $10 \%$ CWMB gained the highest value and the lowest value was for 5\% SWMB. It may be due to the high content of chocolate powder in $10 \%$ CWMB which caused decreasing in the moisture content; however strawberry decreased the (TSS) because of its higher moisture content as compared to the control. 
Table (15): Physical properties of selected fruit \& chocolate wheat milk beverages.

\begin{tabular}{|c|c|c|c|c|c|}
\hline \multirow{2}{*}{ Samples } & \multicolumn{5}{|c|}{ Test items } \\
\cline { 2 - 6 } & Viscosity & TSS\% & Pectin \% & Color & pH value \\
\hline "Control" WMB & 36 & 13.5 & 0.73 & ND & 6.35 \\
\hline $5 \%$ SWMB & 40 & 10.5 & 0.123 & 0.076 & 6.31 \\
\hline $5 \%$ MWMB & 45 & 12.5 & 0.070 & 0.080 & 6.38 \\
\hline $10 \%$ CWMB & 30 & 19.0 & 0.065 & 0.070 & 6.79 \\
\hline
\end{tabular}

WMB: Wheat Milk Beverage; SWMB: Strawberry Wheat Milk Beverage; MWMB: Mango Wheat Milk Beverage; CWMB: Chocolate Wheat Milk Beverage; TSS: Total Soluble Solid and ND: Not detected.

Data shows also that pectin values recorded $(0.73,0.123,0.070$ and 0.065) for the control, 5\% SWMB, 5\% MWMB and 10\% CWMB respectively. The highest value was for the control due to its higher content of milk compared to other beverages and the lowest value was for $10 \%$ CWMB due to its lower content of milk compared to other beverages. In the same table, it observed that the color not detected in the control due to it has no additives; however the color values were $(0.076,0.080$ and 0.070$)$ for 5\% SWMB, 5\% MWMB and 10\% CWMB, respectively. It could be noticed from Table (15) that $\mathrm{pH}$ values recorded $(6.35,6.31,6.38$ and 6.79) for the control and 5\% SWMB, 5\% MWMB and 10\% CWMB respectively. The highest $\mathrm{pH}$ value was for $10 \% \mathrm{CWMB}$ due to its higher content of chocolate powder; however the lowest $\mathrm{pH}$ value was for 5\% SWMB due to its content of strawberry which has higher acidity as compared to the control and other beverages. Prakash et al. (2010) said that the apparent viscosity and sedimentation of UHT-processed chocolate milk increased with increasing concentration of carrageenan and sugar. Main differences in color of chocolate flavored milk beverages samples were detected for parameter $\mathrm{L}^{*}$ (brightness), ranging from very light $\left(\mathrm{L}^{*}=53.5\right)$ to dark $\left(\mathrm{L}^{*}=18.3\right)$ samples (Yanes et al., 2002). They also reported that there is practically no information on physical properties of flavored milk beverages, particularly on color and flow behavior, despite their evident dependence on initial formulation and their considerable influence on consumer acceptance. Color of food is an important quality parameter that may determine acceptability or rejection by the consumer (Abdullah et al., 2008). Color is important in 
flavor and taste recognition and identification, as well as in food preference (Gifford \& Clydesdale, 1986); Children often prefer beverages and other products with attractive colors rather as opposed to colorless foods. Color of food has a psychological effect on how the product is perceived by the consumer. For example, the degree of sweetness in cherry-flavored drinks was perceived by consumers different because of the presence of redcolored pigments.

\subsection{Microbiological evaluation:}

\subsubsection{Total microbial evaluation $(\log 10 / \mathrm{cfu} / \mathrm{ml})$ of selected fruit \& chocolate wheat milk beverages.}

Total microbial count of $15 \%$ wheat milk beverage (WMB) the control and its treatments $5 \%$ strawberry wheat milk beverage (SWMB), 5\% mango wheat milk beverage (MWMB) and $10 \%$ chocolate wheat milk beverage (CWMB) are presented in Table (16). As shown in the table, the total bacterial count of pasteurized four wheat milk beverages were not detected at initial because of the good pasteurization which killed the microorganisms. The addition of fruit and chocolate caused high significant differences in the total bacterial count between the control and wheat milk beverages (5\% strawberry, 10\% mango and $15 \%$ chocolate) at $\mathrm{d} 2$; however there were no growth in total bacterial count in the control. During the storage periods for 3 and 7 days at $4^{\circ} \mathrm{C}$ there were no significant differences between strawberry beverage and the control, however adding strawberry caused high significant differences in total bacterial count $(\mathrm{p}<0.01)$ between strawberry beverage and the control on $\mathrm{d} 14$ and $\mathrm{d} 21$. Mango caused significant differences in total bacterial counts $(\mathrm{p}<0.05)$ for mango wheat milk beverage in comparison with the control on $d 3$, however it caused highly significant differences on d 7, 14 and 21(p<0.01). High 
Table (16): Total microbial evaluation $(\log 10 / \mathrm{cfu} / \mathrm{ml})$ of selected fruit \& chocolate wheat milk beverages.

\begin{tabular}{|c|c|c|c|c|c|c|}
\hline \multicolumn{2}{|c|}{ Samples } & \multicolumn{5}{|c|}{ Storage days } \\
\cline { 3 - 7 } & Initial & 3 & 7 & 14 & 21 \\
\hline \multirow{2}{*}{$\begin{array}{c}\text { Control" } \\
\text { WMB }\end{array}$} & Mean & ND & 2.200 & 2.881 & 5.908 & 6.007 \\
\cline { 2 - 7 } & SE & - & 0.100 & 0.036 & 0.005 & 0.003 \\
\hline \multirow{2}{*}{$5 \%$ SWMB } & Mean & ND & 2.534 & 3.036 & $3.307^{* *}$ & $5.876^{* *}$ \\
\cline { 2 - 7 } & SE & - & 0.119 & 0.046 & 0.018 & 0.006 \\
\hline \multirow{2}{*}{$5 \%$ MWMB } & Mean & ND & $2.660^{*}$ & $3.442^{* *}$ & $6.235^{* *}$ & $7.427^{* *}$ \\
\cline { 2 - 7 } & SE & - & 0.058 & 0.045 & 0.005 & 0.003 \\
\hline \multirow{2}{*}{$10 \%$ CWMB } & Mean & ND & $2.774 * *$ & 3.017 & $3.032^{* *}$ & $3.04 * *$ \\
\cline { 2 - 7 } & SE & - & 0.042 & 0.012 & 0.047 & 0.022 \\
\hline \multicolumn{2}{|c|}{ F value } & - & 8.297 & 41.388 & 4.275 & 2.254 \\
\hline \multicolumn{2}{|c|}{ Sig } & - & 0.008 & 0.000 & 0.000 & 0.000 \\
\hline
\end{tabular}

WMB: Wheat Milk Beverage; SWMB: Strawberry Wheat Milk Beverage; MWMB: Mango Wheat Milk Beverage; CWMB: Chocolate Wheat Milk Beverage; SE: Standard Error and Mean values in each column having different superscript $(*, * *)$ as $\left(^{*}\right)$ indicates the significant difference $(\mathrm{p}<0.05),(* *)$ indicates high significant difference $(\mathrm{p}<0.1)$.

differences in total bacterial count $(\mathrm{p}<0.01)$ were observed in chocolate wheat milk beverage in comparison with the control on $\mathrm{d} 3,14$ and 21 , however there was no significant differences in total bacterial count between the control and chocolate beverage on d 7. Desmasures et al. (1997) found that the level of contamination of refrigerated raw milk samples varied greatly from one farm to another. Average Lactococcus spp. counts were $3.4 \times 102 \mathrm{cfu} \mathrm{mL-1}$ in milk. Average yeasts counts were of $6.9 \times 10$ for milk, while average Pseudomonas spp. counts were of $5.8 \times 102$. Also Aguirre et al. (2010) mentioned that pasteurization must be conducted to inactivate the pathogenic microorganisms in food, to reduce the load of spoilage microorganisms and enzymatic activity, and to extend the shelf-life of the product. However, the shelf-life of fluid milk products, supplied as an enhancement to group rations, is sometimes limited because of the processing conditions, shipping and extreme conditions experienced during storage in rugged environments. Pasteurization of cow's milk initially destroys any potential pathogens and increases the shelf-life (Sean, 2006). Also Fuller et al. (1942) concluded that cocoa powders or chocolate syrups (excepting those flavored with cocoa extracts) added to milk definitely 
$=$

inhibit the growth of bacteria likely to be found in milk, with the exception of Streptococcus lactis, and that the tannic substances of the cocoa products are the agents responsible for inhibiting bacterial growth.

\subsubsection{Spor-formers count $(\log 10 / \mathrm{cfu} / \mathrm{ml})$ of selected fruit \& chocolate wheat milk beverages:}

Sore-formers count of $15 \%$ wheat milk beverage (WMB) the control and its treatments 5\% strawberry wheat milk beverage (SWMB), 5\% mango wheat milk beverage (MWMB) and 10\% chocolate wheat milk beverage (CWMB) are presented in Table (17). As shown in the table, no growth of spore-forming bacteria were detected in the control or beverages at initial or on d 3, it may be due to the good pasteurization of beverages, however spore-forming bacteria were found in small numbers in the control and all beverages on $\mathrm{d} 7,14$ and 21 of storage period at $4^{\circ} \mathrm{C}$. High significant differences between the control and mango wheat milk beverage were observed on $\mathrm{d} 21$ which recorded a higher value $(1.935 \pm 0.032)$ for $5 \%$ mango beverage. These results were in line with Sean (2006) who mentioned that pasteurization of cow's milk initially destroys any potential pathogens and increases the shelf-life. No bacterial cells, spores, yeasts or moulds were observed in chocolate-flavored peanut beverage (Rustom et al., 1996).

\subsubsection{Yeast \& mold count $(\log 10 / \mathrm{cfu} / \mathrm{ml})$ of selected fruit \& chocolate wheat milk beverages:}

Yeast and mold count of $15 \%$ wheat milk beverage (WMB) the control and its treatments 5\% strawberry wheat milk beverage (SWMB), 5\% mango wheat milk beverage (MWMB) and 10\% chocolate wheat milk beverage (CWMB) are presented in Table (18). As shown in Table (18) no growth of (yeast \& molds) was detected in shelf- life of four beverages at initial or on $\mathrm{d} \mathrm{3,7}$ and 14 at $4^{\circ} \mathrm{C}$. This indicates that proper care was taken to avoid contamination throughout the process and there was no post processing contamination; however the growth of (yeast \& molds) was detected in self life of the control and other beverages on $d 21$. Values 
ranged between $1.318 \pm 0.159$ and $2.110 \pm 0.038$. The highest value was for $10 \%$ chocolate wheat milk beverage (CWMB) and the lowest value was for $5 \%$ strawberry wheat milk beverage (SWMB). Adding mango caused a significant difference in yeast \& molds count between the control and $5 \%$ mango wheat milk beverage (MWMB) for 5\% MWMB, however adding chocolate caused high significant difference in yeast $\&$ molds count between the control and $10 \% \mathrm{CWMB}$.

Table (17): Spor-formers count $(\log 10 / \mathrm{cfu} / \mathrm{ml})$ of selected fruit \& chocolate wheat milk beverages.

\begin{tabular}{|c|c|c|c|c|c|c|}
\hline \multicolumn{2}{|c|}{ Samples } & \multicolumn{5}{|c|}{ Storage days } \\
\cline { 3 - 7 } & Initial & 3 & 7 & 14 & 21 \\
\hline \multirow{3}{*}{ "Control" WMB } & Mean & ND & ND & 1.000 & 1.100 & 1.200 \\
\cline { 2 - 7 } & SE & - & - & 0.000 & 0.100 & 0.100 \\
\hline \multirow{2}{*}{$5 \%$ SWMB } & Mean & ND & ND & 1.100 & 1.100 & 1.200 \\
\cline { 2 - 7 } & SE & - & - & 0.100 & 0.100 & 0.100 \\
\hline \multirow{2}{*}{$5 \%$ MWMB } & Mean & ND & ND & 1.200 & 1.359 & $1.935^{* *}$ \\
\cline { 2 - 7 } & SE & - & - & 0.100 & 0.580 & 0.032 \\
\hline \multirow{2}{*}{$10 \%$ CWMB } & Mean & ND & ND & 1.100 & 1.100 & 0.159 \\
\cline { 2 - 7 } & SE & - & - & 0.100 & 0.100 & 0.159 \\
\hline F value & & - & - & 0.889 & 1.999 & 12.091 \\
\hline \multicolumn{2}{|c|}{ Sig } & - & - & 0.487 & 0.193 & 0.002 \\
\hline
\end{tabular}

WMB: Wheat Milk Beverage, SWMB: Strawberry Wheat Milk Beverage; MWMB: Mango Wheat Milk Beverage; CWMB: Chocolate Wheat Milk Beverage; SE: Standard Error and Mean values in each column having different superscript (**) as (**) indicates high significant difference $(\mathrm{p}<0.1)$. 
Table (18): Yeast \& mold counts $(\log 10 / \mathrm{cfu} / \mathrm{ml})$ of selected fruit $\&$ chocolate wheat milk beverages.

\begin{tabular}{|c|c|c|c|c|c|c|}
\hline \multirow{2}{*}{ Samples } & \multicolumn{5}{c|}{ Storage days } \\
\cline { 3 - 7 } & Initials & 3 & 7 & 14 & 21 \\
\hline \multirow{2}{*}{$\begin{array}{c}\text { Control" } \\
\text { WMB }\end{array}$} & Mean & ND & ND & ND & ND & 1.418 \\
\cline { 2 - 7 } & SE & - & - & - & - & 0.058 \\
\hline \multirow{2}{*}{$5 \%$ SWMB } & Mean & ND & ND & ND & ND & 1.318 \\
\cline { 2 - 7 } & SE & - & - & - & - & 0.159 \\
\hline \multirow{2}{*}{$5 \%$ MWMB } & Mean & ND & ND & ND & ND & $1.883^{*}$ \\
\cline { 2 - 7 } & SE & - & - & - & - & 0.019 \\
\hline \multirow{2}{*}{$10 \%$ CWMB } & Mean & ND & ND & ND & ND & $2.110 * *$ \\
\cline { 2 - 7 } & SE & - & - & - & - & 0.038 \\
\hline F value & & - & - & - & - & 18.552 \\
\hline Sig & & - & - & - & - & 0.001 \\
\hline
\end{tabular}

WMB: Wheat Milk Beverage; SWMB: Strawberry Wheat Milk Beverage; MWMB: Mango Wheat Milk Beverage; CWMB: Chocolate Wheat Milk Beverage; SE: Standard Error and Mean values in each column having different superscript (*,**) as (*) indicates the significant difference $(\mathrm{p}<0.05),(* *)$ indicates high significant difference $(\mathrm{p}<0.1)$. 


\section{REFERENCES}

1. Abdullah, S U; Badaruddin, M; Sayeed, S A; Ali, R and Riaz, M N (2008): Binding ability of Allura Red with food proteins and its impact on protein digestibility. Food Chemistry, 110: 605-610.

2. Aguirre, D B; Yáñez, J A; Dunne, C P; Davies, N M and Cánovas, G V B (2010): Study of strawberry flavored milk under pulsed electric field processing. Food Research International, 43(8): 2201-2207.

3. Alsmeyer, A R; Cunningham, A E and Happich, M L (1974): Equation predicts PER from amino acid analysis. Food Tech., 7: $34-40$.

4. Anon (1985): Energy and Protein requirements. Report of join FAO/WHO /UNV Expert Consultation, World Health Organization, Technical, Report, Series, 724 WHO Geneva.

5. Anon (1989): RDA Recommended dietary allowances food and nutritive board. National Academy of Sci, National Res. Council. Washington, D.C.

6. A.O.A.C. (1995): Official methods of analysis Association of Official Analytical Chemists. 15th Ed. Washington, D.C.

7. A.O.A.C. (2000): Official methods of analysis Association of Official Analytical Chemists. 13th Ed. Published Chemists, Washington D.C.U.S.A.

8. A.P.H.A (1971): American Public Health Association. Recommended method for the microbiological examination of foods. Amer. Public health Association, Inc., New York.

9. A.P.H.A. (1992): American U.S.A. public Health Assoc. Standard methods for examination of dairy products. 16th Ed, Washington D.C.

10. Armitage, P (1971): Statistical Methods in Medical Research. Blackwell Scientific Publications, London.

11. Bisig, W (2011): Liquid Milk Products: Flavored Milk. Encyclopedia of Dairy Sciences, 301-306.

12. Blanco, A; deGiovanni, C; Laddomada, B; Sciancalepore, A; Simeone, R; Devos, K M and Gale, M D (1996): Quantitative trait loci influencing grain protein content in tetraploid wheat. Plant Breeding, 116: 310-316.

13. Chalmer, C H (1962): Bacteria in relation to the milk supply 4th Ed. , London.

14. Chavarro, J E; Rich-Edwards, R J W; Rosner, B and Willett, W C (2007): A prospective study of dairy foods intake and anovulatory infertility. Human Reproduction, 22 (5): 1340-7. 
15. Desmasures, N; Opportune, W and Guéguen, M (1997): Lactococcus spp., yeasts and Pseudomonas spp. on teats and udders of milking cows as potential sources of milk contamination. International Dairy Journal, 7(10): 643-646.

16. Dessouki, T M T and Hassanin, M (1995): Cultured Carp as imported frozen herring substitution fish smoking manufacture. J. agric. Sci. Mansoura Univ., 20(10): 4369 - 4380.

17. Edwards, R J W; Ganmaa, D; Pollak, M N; Nakamoto, E K and Kleinman, K (2007): Milk consumption and the prepubertal somatotropic axis. Nutr J., 27; $6: 28$.

18. El-Sanafiry, Y A N (1983): MANUFACTURING OF BALANCED PROTEIN SUPLMENTS. Ph.D. Thesis, Fac. of Agric., Ain Shams Univ.

19. Fuller, J E; Mueller, W S and Swanson, R W (1942): Bacteriological Study of Chocolate Milk. Journal of Dairy Science, 25(10): 883-894.

20. Gifford, S R and Clydesdale, F M (1986): The psychophysical relationship between color and sodium chloride concentrations in model systems. Journal of Food Protection, 49 (12): 977-982.

21. Guo, M (2011): Liquid Milk Products: Modified Milks. Encyclopedia of Dairy Sciences, 97-300.

22. Harold, M (1984): Milk and Dairy Products. On Food and Cooking: The Science and Lore of the Kitchen, New York: Charles Scribner's Sons : 3-53.

23. Hawk, P D; Oser, B L and summerson, W H (1949): Practical physiology chemistry. J. Nutrition, 12: 962.

24. Hendel, C E; Baileg, O F and Taylor, D H (1950): Measurement of none enzymatic browning of dehydrated vegetables during storage. Food Tech., June $12,344-347$.

25. Jaan, K (2001): "Paving the Way for ESL". Dairy Foods.

26. Jiang, X L; Tian, J; Hao, Z and Zhang, W (2008): Protein Content and Amino Acid Composition in Grains of Wheat-Related Species. Agricultural Sciences in China, 7 (3): 272-279.

27. Johnson, R K; Frary, C and Wang, M Q (2002): The nutritional consequences of flavored milk consumption by school-aged children and adolescents in the United States. Journal of the American Dietetic Association, 102(6): 853-856.

28. Kosikowski, F V (1969): Flavored Buttermilks. Journal of Dairy Science, 52(6): 799-800. 
29. Ling, E R (1963): A Text book of Dairy chemistry. vol. II Chapman and Hall Ltd., London . UK 3rd Ed.

30. Liu, R H (2007): Whole grain phytochemicals and health. Journal of Cereal Science, 46(3): 207-219.

31. McCane, C; Widdowson; Scherz and Kloos (2007): "Milk analysis". North Wales Buffalo. International Laboratory Services, Archived from the original on 2007-09-29 .

32. Miller, G D; Jarvis, J K and McBean, L D (2007): Handbook of Foods and Nutrition. 3 rd Boca Raton, FL: CRC Press.

33. Millipore Co-operative (1987): Liquid Chromatographic Analysis of Amino Acids in foods using a Modification of the PICO - Tag method. New York, U.S.A.

34. Moor, M L (1970): Introducing Foods, Laboratory Manual of Food Preparation and Evaluation. 2nd Ed. MacMillan. pub. Co. Inc., New York, Coclier, London.

35. Moore, R H S; Thompson, D; Affenito, S G; Franko, D L; Obarzanek, E; Barton, B A; Schreiber, G B; Daniels, S R; Schmidt, M and Crawford, P B (2006): Correlates of beverage intake in adolescent girls: The National Heart, Lung, and Blood Institute Growth and Health Study. The Journal of Pediatrics, 148 (2): 183-187.

36. Murphy, M; Douglass, J; Latulippe, M; Barr, S; Johnson, R; Frye, C (2005): Beverages as a source of energy and nutrients in the diets of children and adolescents [abstract 275.4]. Experimental Biology and XXXV International Congress of Physiological Sciences meeting abstracts [on CD-ROM].

37. Nebot, M J G; Alegría, A; Barberá, R; Clemente, G and Fernando, R F (2010): Addition of milk or caseinophosphopeptides to fruit beverages to improve iron bioavailability?. Food Chemistry, 119(1): 141-148.

38. Nicklas, TA. (2003): Calcium intake trends and health consequences from childhood through adulthood. J Am Coll Nutr., 22(5): 340-56.

39. Policegoudra, R S and Aradhya, S M (2008): Structure and biochemical properties of starch from an unconventional source-Mango ginger (Curcuma amada Roxb.) rhizome. Food Hydrocolloids, 22(4): 513- 519.

40. Prakash, S; Huppertz, T; Karvchuk, o and Deeth, H (2010): Ultra-hightemperature processing of chocolate flavored milk. Journal of Food Engineering, 96(2): 179-184. 
41. Reitmeier, L Y U and Love, M H (1996): Strawberry texture and pectin content as affected by electron Beam irradiation. J. Food Sci., 61(4): 844-846.

42. Ribeiro, S M R and Schieber, A (2010): Bioactive Compounds in mango (Mangifera indica L.). Bioactive Foods in Promoting Health: 507-523.

43. Rustom, I Y S; López-Leiva, M H and Nair, B H (1996): Nutritional, sensory and physicochemical properties of peanut beverage sterilized under two different UHT conditions. Food Chemistry, 56(1): 45-53.

44. Sean, C (2006): Milk's online top-up, BBC News Online 28 March 2006.

45. Subar, A F; Smith, S M K; Cook, A and Kahle, L L (1998): Dietary sources of nutrients among US children, 1989-1991. Pediatrics (102): 913-92.

46. USDA National Nutrient Database for Standard Reference (2008): Nutrient Data Laboratory Home Page US Department of Agriculture, Agricultural Research Service Web site http://www.ars.usda.gov/ba/bhnrc/ndl Accessed February 16, 2008, Release 20.

47. Wiley, A S (2005): Does milk make children grow? Relationships between milk consumption and height in NHANES 1999 - 2002. Am J Hum Biol, 17(4): 425- 41.

48. Wiley, A S (2009): Consumption of milk, but not other dairy products, is associated with height among US preschool children in NHANES 1999-2002. Ann Hum Biol, 36(2): 125-38.

49. Yanes, M; Durán, L and Costell, E (2002): Rheological and optical properties of commercial chocolate milk beverage. Journal of Food Engineering, 51(3): 229-234.

50. Yegin, S and Uren, A (2008): Biogenic amine content of boza: A traditional cereal-based, fermented Turkish beverage. Food Chemistry, 111 (4): 983-987. 


\section{التقييم الكيسمياُي والمسي والفيرنيأي والميكروبيهولوجي لثلاثة}

\section{هشروبات لبنية هبتكرة للأطفال}

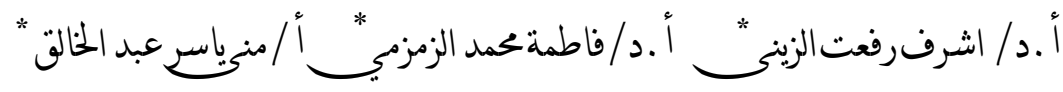

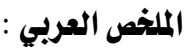

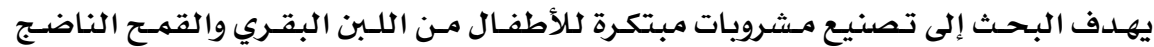

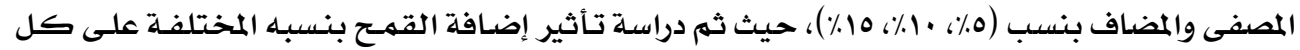

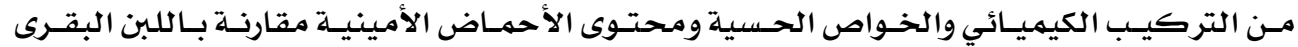

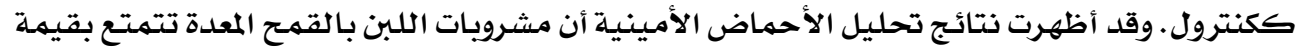

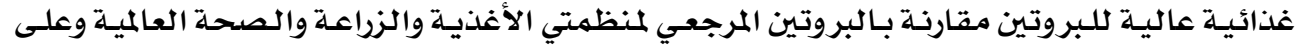

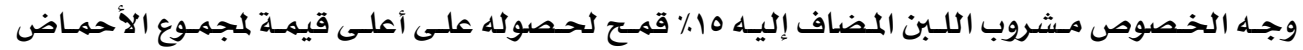

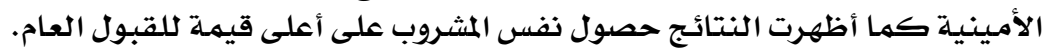

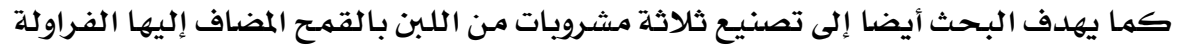

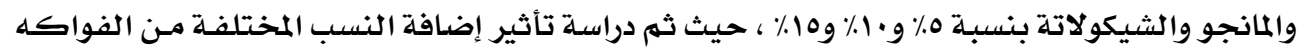

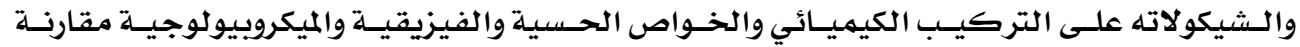

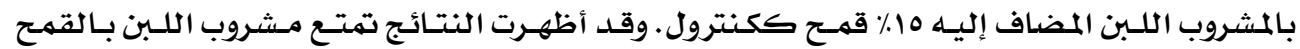

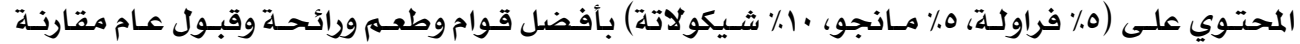

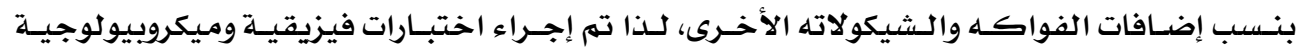

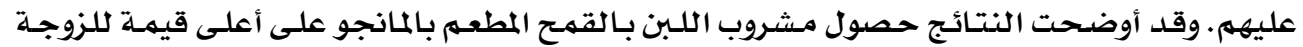

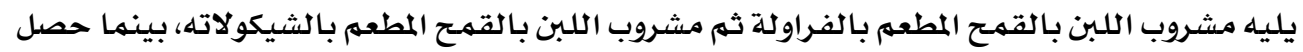

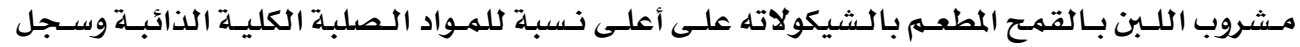

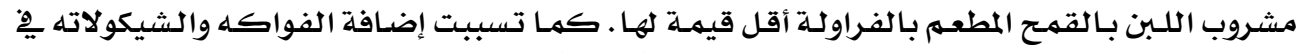

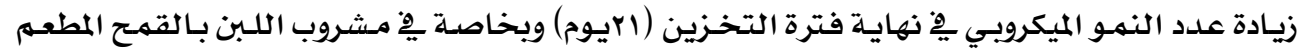

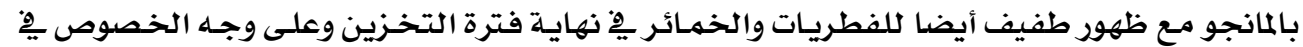

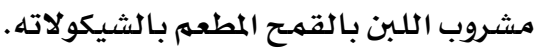

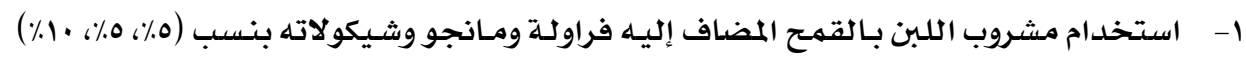

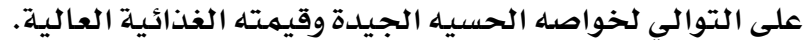

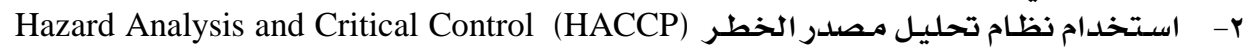
Point للمستهلك. 